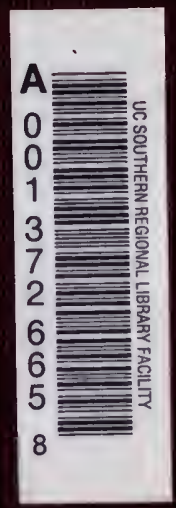




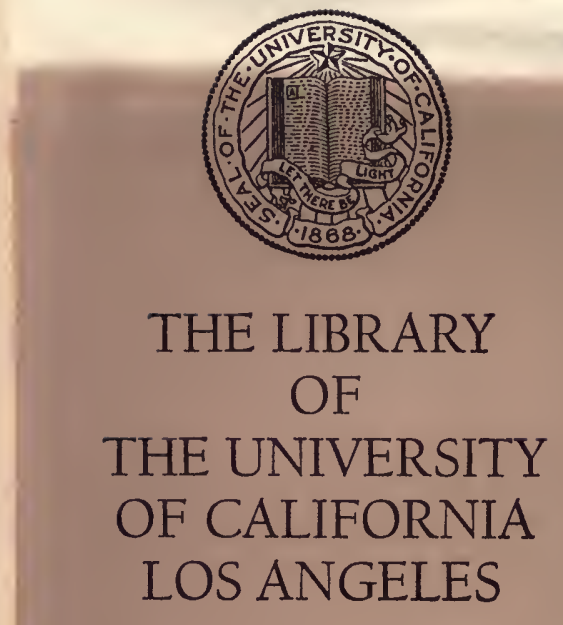

he would call into consuitation $n$ the next few days the chairmen two government agencies having it contact with transporation ems-the interstate commerce - Conferences with rallway manand employes are expected to $\checkmark$ in time to permit action at the ig special session of Congress.

y Rumblings of Dissatisfuction cussion at the cabinet meeting only of a preliminary and indecharacter, but there were indiis that the chief executive and ficlal advisers were much cond over information which o las come into their possession. it took up the reins of authoric administration has heard rum3 of dissatisfaction from many es, the roads complaining of in- 


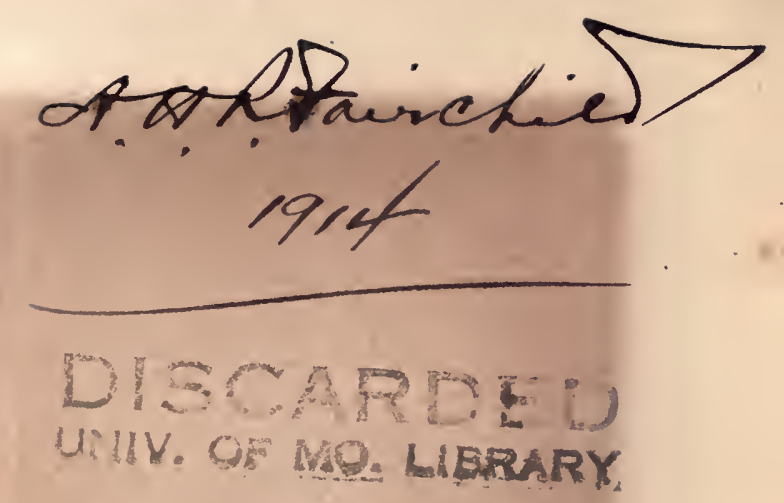





\title{
RIVERSIDE ESSAYS
}

EDITED BY

\author{
ADA L. F. SNELL
}

ASSOCIATE PROFESSOR OF ENGLISH MOUNT HOLYOKE COLLEGE 


\section{Riberside Essays Eviter by Ara L. J. Snell}

THE AMERICAN MIND AND AMERICAN IDEALISM. By Bliss Perry. 35 cents.

UNIVERSITY SUBJECTS. By John Henry Newman. 35 cents.

STUDIES IN NATURE AND LITERATURE. By John Burroughs. 35 cents.

PROMOTING GOOD CITIŻENSHIP, By James Bryce. 35 cents

Prices are net, postpaid

Other titles in preparation

HOUGHTON MIFFLIN COMPANY

Boston Nhw York Chicago 


\section{The Jiberside Literature Seríes}

\section{STUDIES IN NATURE AND LITERATURE}

BY

\section{JOHN BURROUGHS}

or Man $79-192$.

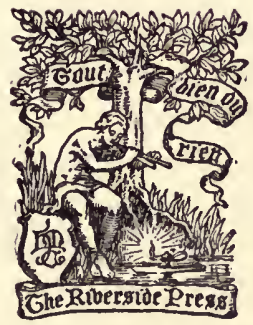

BOSTON NEW YORK CHICAGO HOUGHTON MIFFLIN COMPANY The liver pre fambrioge 
COPYRIGHT, $1875,1859,1 S_{94}, 1902,1903$, AND 199, BY јОHN BURROUGHS

ALL RIGHTS RESERVED

R. L. S, 226

Cbe Riberside Press

CAMBRIDGE - MASSACHUSRTTS

u. S . A 


\section{PS
1224
593}

\section{PREFACE}

MR. BURRoughs has written of himself in 1 an "Egotistical Chapter" so revealingly and withal so concisely that it makes the most fitting introduction to this little volume of selections from the works of our greatest literary naturalist. The choosing of material from fifteen by no means slender volumes has been a difficult task; how many favorites one would like to include, such as "The Hunt for the Nightingale," "The Apple," "The Grist of the Gods" - but one must not make a catalogue in a preface! It is hoped, however, that the material which has been selected and is here presented may serve to increase the interest of students in the writings of Mr. Burroughs, and that it may encourage them to read and express on their own account the world which he has made known to us as a place abounding in miracles.

Ada L. F. SNell. 


\section{CONTENTS}

An Egotistical Chapter . . . . . . . 1

The Exhilarations of the Road . . . . 19

Bird Liffe in an Old Apple-Tree . . . . . 38

Bird Courtship . . . . . . . . . . 45

The Srow-Walkers . . . . . . . . 56

Among the Wild Flowers . . . . . . . 62

The Drvine Soll . . . . . . . . . . 69

Style and the Man . . . . . . . . . . 82

Suggestiveness . . . . . . . . . 101 



\section{AN EGOTISTICAL CHAPTER ${ }^{1}$}

AEW years ago the editor of a popular magaA zine inveigled a good many people, myself among the number, into writing about themselves and their experiences in life. None of us, I imagine, needed very much persuading, for as a rule there is no subject which a man or a woman is more ready or willing to talk about than himself or herself. One's ailments are always a favorite subject; next to that, one's good luck or ill luck in his last undertaking; then one's experiences, one's likes and dislikes; and lastly, self-analysis and criticism. And it has been said that a man "is never so sure to please as when he writes of himself with good faith, and without affectation." Ay, there's the rub ; to write of one's self without affectation! A false note of this kind is fatal to the interest and value of the criticism.

In a certain sense, a man of the literary or artistic temperament never portrays or writes of anything but himself; that is, he gives us things as seen through the intimate personal medium which he himself is. All things reflect his hue and quality.

\section{From Indoor Studies.}


This is the bane of science, but it is the life of literature. I have probably unwittingly written myself in my books more fully and frankly than I ever can by any direct confession and criticism; but the latter may throw some side light at least, and, on looking over what I wrote for the editor above referred to, I find that portions of it possess a certain interest and value to myself, and therefore I trust may not seem entirely amiss to my reader.

If a man is not born into the environment best suited to him, he, as a rule, casts about him until he finds such environment. My own surroundings and connections have been mainly of the unliterary kind. I was born of and among people who neither read books nor cared for them, and my closest associations since have been with those whose minds have been alien to literature and art. My unliterary environment has doubtless been best suited to me. Probably what little freshness and primal sweetness my books contain is owing to this circumstance. Constant intercourse with bookish men and literary circles I think would have dwarfed or killed my literary faculty. This perpetual rubbing of heads together, as in the literary clubs, seems to result in literary sterility. In my own case, at least, what I most needed was what I had, - a few books and plenty of real things. I never had any aptitude for scholarly attainments; my verbal or artificial memory, so to speak, was poor, but my mind 
always had a certain magnetic or adhesive quality for things that were proper to it and that belonged to me.

I early took pleasure in trying to express myself on paper, probably in my sixteenth or seventeenth year. In my reading I was attracted by everything of the essay kind. In the libraries and bookstores I was on the lookout for books of essays. And I wanted the essay to start, not in a casual and inconsequential way, but the first sentence must be a formal enunciation of a principle. I bought the whole of Dr. Johnson's works at a second-hand bookstore in New York, because, on looking into them, I found his essays appeared to be of solid essay-stuff from beginning to end. I passed by Montaigne's Essays at the same time, because they had a personal and gossipy look. Almost my first literary attempts were moral reflections, somewhat in the Johnsonian style. I lived on the "Rambler" and the "Idler" all one year, and tried to produce something of my own in similar form. As a youth I was a philosopher; as a young man I was an Emersonian; as a middle-aged man I am a literary naturalist; but always have I been an essayist.

It was while $I$ was at school, in my nineteenth year, that I saw my first author; and I distinctly remember with what emotion I gazed upon him, and followed him in the twilight, keeping on the other side of the street. He was of little account, - 
a man who had failed as a lawyer, and then had written a history of Poland, which I have never heard of since that time; but to me he was the embodiment of the august spirit of authorship, and I looked upon him with more reverence and enthusiasm than I had ever looked before upon any man. I do not think I could have approached and spoken to him on any consideration. I cannot at this date divine why I should have stood in such worshipful fear and awe of this obscure individual, but I suppose it was the instinctive tribute of a timid and imaginative youth to a power which he was just beginning vaguely to see, - the power of letters.

It was at about this time that I first saw my own thoughts in print, - a communication of some kind to a little country paper published in an adjoining town. In my twenty-second or twenty-third year, I began to send rude and crude essays to the magazines and to certain New York weekly papers, but they came back again pretty promptly. I wrote on such subjects as "Revolutions," "A Man and his Times," "Genius," "Individuality." At this period of my life I was much indebted to Whipple, whose style, as it appears in his earlier essays and in the thin volume of lectures published by Ticknor, Reed \& Fields about 1853, is, in my judgment, much better than in his later writings. It was never a good style, not at all magnetic or penetrating, but it was clear and direct, and, to my mind at that 
period, stimulating. Higginson had just begun to publish his polished essays in the "Atlantic," and I found much help in them also. They were a little cold, but they had the quality which belongs to the work of a man who looks upon literature as a fine art. My mind had already begun to turn to outdoor themes, and Higginson gave me a good send-off in this direction. But the master-enchanter of this period of my life and of many following years was Emerson. While at school, in my nineteenth year, in my search for essays I had carried to my room one volume of his, but I could do nothing with it. What, indeed, could a Johnsonian youth make of Emerson? A year or so later I again opened one of his books in a Chicago bookstore, and was so taken with the first taste of it that I then and there purchased the three volumes, - the "Essays" and the "Miscellanies." All that summer I fed upon them and steeped myself in them: so that when, a year or two afterwards, I wrote an essay on "Expression" and sent it to the "Atlantic," it was so Emersonian that the editor thought some one was trying to palm off on him an early essay of Emerson's which he had not seen. Satisfying himself that Emerson had published no such paper, he printed it in the November number of 1860. It had not much merit. I remember this sentence, which may contain some truth aptly put: "Dr. Johnson's periods act like a lever of the third 
kind: the power applied always exceeds the weight raised."

It was mainly to break the spell of Emerson's influence and to get upon ground of my own that I took to writing upon outdoor themes. I wrote half a dozen or more sketches upon all sorts of open-air subjects, which were published in the New York "Leader." The woods, the soil, the waters, helped to draw out the pungent Emersonian flavor and restore me to my proper atmosphere. But to this day I am aware that a suggestion of Emerson's manner often crops out in my writings. His mind was the firmer, harder substance, and was bound to leave its mark upon my own. But, in any case, my debt to him is great. He helped me to better literary expression, he quickened my perception of the beautiful, he stimulated and fertilized my religious nature. Unless one is naturally more or less both of a religious and of a poetic turn, the writings of such men as Emerson and Carlyle are mainly lost upon him. Two thirds of the force of these writers, at least, is directed into these channels. It is the quality of their genius, rather than the scope and push of their minds, that endears them to us. They quicken the conscience and stimulate the character as well as correct the taste. They are not the spokesmen of science or of the reason, but of the soul.

About this period I fell in with Thoreau's "Walden," but I am not conscious of any great debt to 
Thoreau: I had begun to write upon outdoor themes before his books fell into my hands, but he undoubtedly helped confirm me in my own direction. He was the intellectual child of Emerson, but added a certain crispness and pungency, as of wild roots and herbs, to the urbane philosophy of his great neighbor. But Thoreau had one trait which I always envied him, namely, his indifference to human beings. He seems to have been as insensible to people as he was open and hospitable to nature. It probably gave him more pleasure to open his door to a woodchuck than to a man.

Let me confess that I am too conscious of persons, - feel them too much, defer to them too much, and try too hard to adapt myself to them. Emerson says, "A great man is coming to dine with me: I do not wish to please him, I wish that he should wish to please me." I should be sure to overdo the matter in trying to please the great man: more than that, his presence would probably take away my appetite for my dinner.

In speaking of the men who have influenced me, or to whom I owe the greatest debt, let me finish the list here. I was not born out of time, but in good time. The men I seemed to need most were nearly all my contemporaries; the ideas and influences which address themselves to me the most directly and forcibly have been abundantly current in my time. Hence I owe, or seem to owe, more 
to contemporary authors than to the men of the past. I have lived in the present time, in the present hour, and have invested myself in the objects nearest at hand. Besides the writers I have mentioned, I am conscious of owing a debt to Whitman, Ruskin, Arnold, Wordsworth, Coleridge, and Tennyson. To Whitman I owe a certain liberalizing influence, as well as a lesson in patriotism which I could have got in the same measure from no other source. Whitman opens the doors, and opens them wide. He pours a flood of human sympathy which sets the whole world afloat. He is a great humanizing power. There is no other personality in literature that gives me such a sense of breadth and magnitude in the purely human and personal qualities. His poems are dominated by a sense of a living, breathing man as no other poems are. This would not recommend them to some readers, but it recommends them to such as $I$, who value in books perennial human qualities above all things. To put a great personality in poetry is to establish a living fountain of power, where the jaded and exhausted race can refresh and renew itself.

To a man in many ways the opposite of Whitman, who stands for an entirely different, almost antagonistic, order of ideas, - to wit, Matthew Arnold, - I am indebted for a lesson in clear thinking and clean expression such as $I$ have got from no other. Arnold's style is probably the most lucid, 
the least embarrassed by anything false or foreign, of that of any writer living. His page is as clear as science and as vital and flexible as poetry. Indeed, he affords a notable instance of the cool, impartial scientific spirit wedded to, or working through, the finest poetic delicacy and sensibility.

I have not been deeply touched or moved by any English poet of this century save Wordsworth. Nearly all other poetry of nature is tame and insincere compared with his. But my poetic sympathies are probably pretty narrow. I cannot, for instance, read Robert Browning, except here and there a short poem. The sheer mechanical effort of reading him, of leaping and dodging and turning sharp corners to overtale his meaning, is too much for me. It makes my mental bones ache. It is not that he is so subtile and profound, for he is less in both these respects than Shakespeare, but that he is so abrupt and elliptical and plays such fantastic tricks with syntax. His verse is like a springless wagon on a rough road. He is full of bounce and vigor, but it is of the kind that bruises the flesh and makes one bite his tongue. Swinburne has lilt and flow enough, certainly, and yet I cannot read him. He sickens me from the opposite cause : I am adrift in a sea of melodious words, with never an idea to cling to. There is to me something grewsome and uncanny about Swinburne's poetry, like the clammy and rapidly-growing fungi in nature. 
It is not health, but disease; it is not inspiration, but a mortal flux. The "Saturday Review," in noticing my last volume, "Signs and Seasons," intimates that I might have found better specimens of sea-poetry to adorn the chapter called "A Salt Breeze" in Mr. Swinburne than those I have given, and quotes the following stanzas from him as proof:-

"Hardly we saw the high moon hanging,

Heard hardly through the windy night,

Far waters ringing, low reefs clanging,

Under wan skies and waste white light.

"With chafe and change of surges chiming,

The clashing channels rocked and rang

Large music, wave to wild wave timing,

And all the choral waters sang."

Words, words, words! and all struck with the leprosy of alliteration. Such poetry would turn my blood to water. "Wan skies and waste white light," - are there ever any other skies or any other lights in Swinburne?

But this last is an ill wind which I fear can blow no good to any one. I have lived long enough to know that my own private likes and dislikes do not always turn out to be the decrees of the Eternal. Some writers confirm one and brace him where he stands; others give him a lift forward. I am not aware that more than two American writers have 
been of the latter service to me, - Emerson and Whitman. Such a spirit as Bryant is confirmatory. I may say the same of Whittier and Longfellow. I owe to these men solace and encouragement, but no new territory.

Still, the influences that shape one's life are often so subtile and remote, and of such small beginning, that it will not do to be too positive about these matters. At any rate, self-analysis is a sort of backhanded work, and one is lucky if he comes at all near the truth.

As such a paper must of necessity be egotistical, let me not flinch in any part of my task on that account.

What little merit my style has is the result of much study and discipline. I have taught myself always to get down to the quick of my mind at once, and not fumble about amid the husks at the surface. Unless one can give the sense of vitality in his pages, no mere verbal brightness or scholarly attainments will save him. In the best writing, every sentence is filled with the writer's living, breathing quality, just as in the perfected honeycomb every cell is filled with honey. But how much empty comb there is even in the best books! I wish to give an account of a bird, or a flower, or of any open-air scene or incident. My whole effort is to see the thing just as it was. I ask myself, "Exactly how did this thing strike my mind? What 
was prominent? What was subordinated? I have been accused of romancing at times. But it is not true. I set down the thing exactly as it fell out. People say, "I do not see what you do when I take a walk." But for the most part they do, but the fact as it lies there in nature is crude and raw: it needs to be brought out, to be passed through the heart and mind and presented in appropriate words. This humanizes it and gives it an added charm and significance. This, I take it, is what is meant by idealizing and interpreting nature. We do not add to or falsely color the facts: we disentangle them, and invest them with the magic of written words.

To give anything like vitality to one's style, one must divest one's self of any false or accidental or factitious mood or feeling, and get down to his real self, and speak as directly and sincerely as he does about his daily business or affairs, and with as little affectation. One may write from the outside of his mind, as it were, write and write, glibly and learnedly, and make no impression; but when one speaks from real insight and conviction of his own, men are always glad to hear him, whether they agree with him or not. So much writing or speaking is like mere machine-work, as if you turned a crank and the piece or discourse came out. It is not the man's real mind, his real experience. This he does not know how to get at; it has no connection with his speaking or writing faculty. How 


\section{AN EGOTISTICAL CHAPTER}

rare are real poems, - poems that spring from real feeling, a real throb of emotion, and not from a mere surface-itching of the mind for literary expression! The world is full of "rhyming parasites," as Milton called them. The great mass of the poetry of any age is purely artificial, and has no root in real things. It is a kind of masquerading. The stock poetic forms are masks behind which the poetlings hide their real poverty of thought and feeling. In prose one has no such factitious aids; here he must stand upon his own merits; he has not the cloak of Milton or Tennyson, or Spenser, to hide in.

It is, of course, the young writer who oftenest fails to speak his real mind, or to speak from any proper basis of insight and conviction. He is carried away by a fancy, a love of novelty, or an affectation of originality. The strange things, the novel things, are seldom true. Look for truth under your feet. To be original, Carlyle said, is to be sincere. When one is young, how many discoveries he makes, - real mare's-eggs, which by and by turn out to be nothing but field-pumpkins!

Men who, like myself, are deficient in self-assertion, or whose personalities are flexible and yielding, make a poor show in politics or business, but in certain other fields these defects have their advantages. In action, Renan says, one is weak by his best qualities, - such, I suppose, as tender- 
ness, sympathy, religiousness, - and strong by his poorer, or at least his less attractive, qualities. But in letters the reverse is probably true. How many of us owe our success in this field to qualities which in a measure disqualified us for an active career! A late writer upon Carlyle seeks to demonstrate that the "open secret of his life" was his desire to take a hand in the actual affairs of English politics; but it is quite certain that the traits and gifts which made him such a power in literature - namely, his tremendous imagination and his burdened prophetic conscience - would have stood in his way in dealing with the coarse affairs of this world.

In my own case, what hinders me with the world helps me with impersonal nature. I do not stand in my own light. My will, my personality, offer little resistance: they let the shy, delicate influences pass. I can surrender myself to nature without effort, but am more or less restrained and self-conscious in the presence of my fellows. Bird and beast take to me, and I to them. I can look in the eye of an ugly dog and win him, but with an ugly man I have less success.

I have unmistakably the feminine idiosyncrasy. Perhaps this is the reason that my best and most enthusiastic readers appear to be women. In the genesis of all my books, feeling goes a long way before intellection. What I feel I can express, 
and only what I feel. If I had run after the birds only to write about them, I never should have written anything that any one would have cared to read. I must write from sympathy and love, or not at all: I have in no sort of measure the gift of the ready writer who can turn his pen to all sorts of themes; or the dramatic, creative gift of the great poets, which enables them to get out of themselves and to present vividly and powerfully things entirely beyond the circle of their own lives and experiences. I go to the woods to enjoy myself, and not to report them; and if I succeed, the expedition may by and by bear fruit at my pen. When a writer of my limited range begins to "make believe," or to go outside of his experience, he betrays himself at once. My success, such as it is, has been in putting my own personal feelings and attractions into subjects of universal interest. I have loved Nature no more than thousands upon thousands of others have, but my aim has been not to tell that love to my reader, but to tell it to the trees and the birds and to let them tell him. I think we all like this indirect way the best. It will not do in literature to compliment Nature and make love to her by open profession and declaration: you must show your love by your deeds or your spirit, and by the sincerity of your service to her.

For my part, I never can interview Nature in the reporter fashion: I must camp and tramp with her

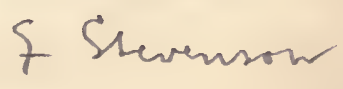


to get any good, and what I get I absorb through my emotions rather than consciously gather through my intellect. Hence the act of composition with me is a kind of sclf-exploration to see what hidden stores my mind holds. If I write upon a favorite author, for instance, I do not give my reader something which lay clearly defined in my mind when $\mathbf{I}$ began to write: I give him what I find, after closest scrutiny, in the subconscious regions, - a result as unknown to me as to him when I began to write. The same with outdoor subjects. I come gradually to have a feeling that $I$ want to write upon a given theme, - rain, for instance, or snow, - but what I may have to say upon it is as vague as the background of one of Millet's pictures; my hope is entirely in the feeling or attraction which draws my mind that way; the subject is congenial, it sticks to me; whenever it recurs to me, it awakens as it were a warm personal response.

Perhaps this is the experience of all other writers: their subjects find them, or bring the key to their hidden stores. Great poets, like Milton, however, cast about them and deliberately choose a theme: they are not hampered by their sympathies, nor are they prisoners of their own personalities, like writers who depend upon this pack of unconscious impressions at their back. An experience must lie in my mind a certain time before $I$ can put it on paper, - say from three to six months. If 
there is anything in it, it will ripen and mellow in that time. I rarely take any notes, and $I$ have a very poor memory, but rely upon the affinity of my mind for a certain order of truths or observations. What is mine will stick to me, and what is not will drop off. When I returned from England after a three months' visit in the summer of 1882 , $\Upsilon$ was conscious of having brought back with me a few observations that I might expand into two or three short essays. But when I began to open my pack, the contents grew so upon my hands that it reached many times the measure $I$ at first proposed. Indeed, when I look back over my seven volumes, I wonder where they have all come from. I am like a boy who at the close of the day looks over his string of fish curiously, not one of which did he know of in the morning, and every one of which oame to his hand from depths beyond his ken by luck and skill in fishing. I have often caught my fish when I least expected to, and as often my most determined efforts have been entirely unavailing.

It is a wise injunction, "Know thyself," but how hard to fulfil! 'This unconscious region in one, this unconscious setting of the currents of his life in certain directions, - how hard to know that! The influences of his family, his race, his times, his environment, are all deeper than the plummet of his self-knowledge can reach. Yet 
how we admire the ready man, the man who always has complete control of his resources, who can speak the right word instantly! My own wit is always belated. After the crisis is past, the right word or the right sentence is pretty sure to appear and mock me by its tardiness.

There is, no doubt, a great difference in men with reference to this knowledge and command of their own resources. Some writers seem to me to be like those military states wherein every man is numbered, drilled, and equipped, and ready for instant service: the whole male population is a standing army. Then there are men of another type who have no standing army. They are absorbed in mere. living, and, when the occasion requires, they have to recruit their ideas slowly from the vague, uncertain masses in the background. Hence they never cut a brilliant figure upon paper, though they may be capable of doing real heartfelt work. 


\section{THE EXHILARATIONS OF THE ROAD ?}

Afoot and light-hearted I take to the open road.

Walt Whitman.

CCASIONALLY on the sidewalk, amid the dapper, swiftly moving, high-heeled boots and gaiters, I catch a glimpse of the naked human foot. Nimbly it scuffs along, the toes spread, the sides flatten, the heel protrudes; it grasps the curbing, or bends to the form of the uneven surfaces, - a thing sensuous and alive, that seems to take cognizance of whatever it touches or passes. How primitive and uncivil it looks in such company, - a real barbarian in the parlor! We are so unused to the human anatomy, to simple, unadorned nature, that it looks a little repulsive; but it is beautiful for all that. Though it be a black foot and an unwashed foot, it shall be exalted. It is a thing of life amid leather, a free spirit amid cramped, a wild bird amid caged, an athlete amid consumptives. It is the symbol of my order, the Order of Walkers. That unhampered, vitally playing piece of anatomy is the type of the pedestrian, man returned to first

1 From Winter Sunshine. 
principles, in direct contact and intercourse with the earth and the elements, his faculties unsheathed, his mind plastic, his body toughened, his heart light, his soul dilated; while those cramped and distorted members in the calf and kid are the unfortunate wretches doomed to carriages and cushions.

I am not going to advocate the disuse of boots and shoes, or the abandoning of the improved modes of travel; but I am going to brag as lustily as I can on behalf of the pedestrian, and show how all the shining angels second and accompany the man who goes afoot, while all the dark spirits are ever looking out for a chance to ride.

When I see the discomforts that able-bodied American men will put up with rather than go a mile or half a mile on foot, the abuses they will tolerate and encourage, crowding the street car on a little fall in the temperature or the appearance of an inch or two of snow, packing up to overflowing, dangling to the straps, treading on each other's toes, breathing each other's breaths, crushing the women and children, hanging by tooth and nail to a square inch of the platform, imperiling their limbs and killing the horses, - I think the commonest tramp in the street has good reason to felicitate himself on his rare privilege of going afoot. Indeed, a race that neglects or despises this primitive gift, that fears the touch of the soil, that has no footpaths, no community of ownership in the land 


\section{THE EXHILARATIONS OF THE ROAD 21}

which they imply, that warns off the walker as a trespasser, that knows no way but the highway, the carriage-way, that forgets the stile, the foot-bridge, that even ignores the rights of the pedestrian in the public road, providing no escape for him but in the ditch or up the bank, is in a fair way to far more serious degeneracy.

Shakespeare makes the chief qualification of the walker a merry heart: -

" Jog on, jog on, the footpath way,

And merrily hent the stile-a;

A merry heart goes all the day,

Your sad tires in a mile-a."

The human body is a steed that goes freest and longest under a light rider, and the lightest of all riders is a cheerful heart. Your sad, or morose, or embittered, or preoccupied heart settles heavily into the saddle, and the poor beast, the body, breaks down the first mile. Indeed, the heaviest thing in the world is a heavy heart. Next to that, the most burdensome to the walker is a heart not in perfect sympathy and accord with the body, - a reluctant or unwilling heart. The horse and rider must not only both be willing to go the same way, but the rider must lead the way and infuse his own lightness and eagerness into the steed. Herein is no doubt our trouble, and one reason of the decay of the noble art in this country. We are unwilling 
walkers. We are not innocent and simple-hearted enough to enjoy a walk. We have fallen from that state of grace which capacity to enjoy a walk implies. It cannot be said that as a people we are so positively sad, or morose, or melancholic, as that we are vacant of that sportiveness and surplusage of animal spirits that characterized our ancestors, and that springs from full and harmonious life, - a sound heart in accord with a sound body. A man must invest himself near at hand and in common things, and be content with a steady and moderate return, if he would know the blessedness of a cheerful heart and the sweetness of a walk over the round earth. This is a lesson the American has yet to learn, - capability of amusement on a low key. He expects rapid and extraordinary returns. He would make the very elemental laws pay usury. He has nothing to invest in a walk; it is too slow, too cheap. We crave the astonishing, the exciting, the far away, and do not know the highways of the gods when we see them, - always a sign of the decay of the faith and simplicity of man.

If I say to my neighbor, "Come with me, I have great wonders to show you," he pricks up his ears and comes forthwith; but when I take him on the hills under the full blaze of the sun, or along the country road, our footsteps lighted by the moon and stars, and say to him, "Behold, these are the wonders, these are the circuits of the gods, this we now 


\section{THE EXHILARATIONS OF THE ROAD 23}

tread is a morning star," he feels defrauded, and as if I had played him a trick. And yet nothing less than dilatation and enthusiasm like this is the badge of the master walker.

If we are not sad, we are careworn, hurried, discontented, mortgaging the present for the promise of the future. If we take a walk, it is as we take a prescription, with about the same relish and with about the same purpose; and the more the fatigue, the greater our faith in the virtue of the medicine.

Of those gleesome saunters over the hills in spring, or those sallies of the body in winter, those excursions into space when the foot strikes fire at every step, when the air tastes like a new and finer mixture, when we accumulate force and gladness as we go along, when the sight of objects by the roadside and of the fields and woods pleases more than pictures or than all the art in the world, - those ten or twelve mile dashes that are but the wit and effluence of the corporeal powers, - of such diversion and open road entertainment, I say, most of us know very little.

I notice with astonishment that at our fashionable watering-places nobody walks; that, of all those vast crowds of health-seekers and lovers of country air, you can never catch one in the fields or woods, or guilty of trudging along the country road with dust on his shoes and sun-tan on his hands and face. The sole amusement seems to be to eat and dress 
and sit about the hotels and glare at each other. The men look bored, the women look tired, and all seem to sigh, "O Lord! what shall we do to be happy and not be vulgar?" Quite different from our British cousins across the water, who have plenty of amusement and hilarity, spending most of the time at their watering-places in the open air, strolling, picnicking, boating, climbing, briskly walking, apparently with little fear of sun-tan or of compromising their "gentility."

It is indeed astonishing with what ease and hilarity the English walk. To an American it seems a kind of infatuation. When Diekens was in this country, I imagine the aspirants to the honor of a walk with him were not numerous. In a pedestrian tour of England by an American, I read that, " after breakfast with the Independent minister, he walked with us for six miles out of town upon our road. Three little boys and girls, the youngest six years old, also accompanied us. They were romping and rambling about all the while, and their morning walk must have been as much as fifteen miles; but they thought nothing of it, and when we parted were apparently as fresh as when they started, and very loath to return."

I fear, also, the American is becoming disqualified for the manly art of walking by a falling off in the size of his foot. He cherishes and cultivates this part of his anatomy, and apparently thinks his 
taste and good breeding are to be inferred from its diminutive size. A small, trim foot, well booted or gaitered, is the national vanity. How we stare at the big feet of foreigners, and wonder what may be the price of leather in those countries, and where all the aristocratic blood is, that these plebeian extremities so predominate! If we were admitted to the confidences of the shoemaker to Her Majesty or to His Royal Highness, no doubt we should modify our views upon this latter point, for a truly large and royal nature is never stunted in the extremities; a little foot never yet supported a great character.

It is said that Englishmen, when they first come to this country, are for some time under the impression that American women all have deformed feet, they are so coy of them and so studiously careful to keep them hid. That there is an astonishing difference between the women of the two countries in this respect, every traveler can testify; and that there is a difference equally astonishing between the pedestrian habits and capabilities of the rival sisters, is also certain.

The English pedestrian, no doubt, has the advantage of us in the matter of climate; for, notwithstanding the traditional gloom and moroseness of English skies, they have in that country none of those relaxing, sinking, enervating days, of which we have so many here, and which seem especially 
trying to the female constitution, - days which withdraw all support from the back and loins, and render walking of all things burdensome. Theirs is a climate of which it has been said that "it invites men abroad more days in the year and more hours in the day than that of any other country."

Then their land is threaded with paths which invite the walker, and which are scarcely less important than the highways. I heard of a surly nobleman near London who took it into his head to close a footpath that passed through his estate near his house, and open another a little farther off. The pedestrians objected; the matter got into the courts, and after protracted litigation the aristocrat was beaten. The path could not be closed or moved. The memory of man ran not to the time when there was not a footpath there, and every pedestrian should have the right of way there still.

I remember the pleasure $I$ had in the path that connects Stratford-on-Avon with Shottery, Shakespeare's path when he went courting Anne Hathaway. By the king's highway the distance is some farther, so there is a well-worn path along the hedgerows and through the meadows and turnip patches. The traveler in it has the privilege of crossing the railroad track, an unusual privilege in England, and one denied to the lord in his carriage, who must either go over or under it. (It is a privilege, is it not, to be allowed the forbidden, even if it be the 


\section{THE EXHILARATIONS OF THE ROAD 27}

privilege of being run over by the engine?) In strolling over the South Downs, too, I was delighted to find that where the hill was steepest some benefactor of the order of walkers had made notches in the sward, so that the foot could bite the better and firmer; the path became a kind of stairway, which I have no doubt the plowman respected.

When you see an English country church withdrawn, secluded, out of the reach of wheels, standing amid grassy graves and surrounded by noble trees, approached by paths and shaded lanes, you appreciate more than ever this beautiful habit of the people. Only a race that knows how to use its feet, and holds footpaths sacred, could put such a charm of privacy and humility into such a structure. I think I should be tempted to go to church myself if I saw all my neighbors starting off across the fields or along paths that led to such charmed spots, and were sure I should not be jostled or run over by the rival chariots of the worshipers at the temple doors. I think that is what ails our religion; humility and devoutness of heart leave one when he lays by his walking shoes and walking clothes, and sets out for church drawn by something.

Indeed, I think it would be tantamount to an astonishing revival of religion if the people would all walk to church on Sunday and walk home again. Think how the stones would preach to them by the wayside; how their benumbed minds would warm 
up beneath the friction of the gravel; how their vain and foolish thoughts, their desponding thoughts, their besetting demons of one kind and another, would drop behind them, unable to keep up or to endure the fresh air! They would walk away from their ennui, their worldly cares, their uncharitableness, their pride of dress; for these devils always want to ride, while the simple virtues are never so happy as when on foot. Let us walk by all means; but if we will ride, get an ass.

Then the English claim that they are a more hearty and robust people than we are. It is certain they are a plainer people, have plainer tastes, dress plainer, build plainer, speak plainer, keep closer to facts, wear broader shoes and coarser clothes, and place a lower estimate on themselves, - all of which traits favor pedestrian habits. The English grandee is not confined to his carriage; but if the American aristocrat leaves his, he is ruined. Oh the weariness, the emptiness, the plotting, the seeking rest and finding none, that go by in the carriages! while your pedestrian is always cheerful, alert, refreshed, with his heart in his hand and his hand free to all. He looks down upon nobody; he is on the common level. His pores are all open, his circulation is active, his digestion good. His heart is not cold, nor are his faculties asleep. He is the only real traveler; he alone tastes the "gay, fresh sentiment of the road." He is not isolated, but is at one with things, 


\section{THE EXHILARATIONS OF THE ROAD}

with the farms and the industries on either hand. The vital, universal currents play through him. He knows the ground is alive; he feels the pulses of the wind, and reads the mute language of things. His sympathies are all aroused; his senses are continually reporting messages to his mind. Wind, frost, rain, heat, cold, are something to him. He is not merely a spectator of the panorama of nature, but a participator in it. He experiences the country he passes through, - tastes it, feels it, absorbs it; the traveler in his fine carriage sees it merely. This gives the fresh charm to that class of books that may be called "Views Afoot," and to the narratives of hunters, naturalists, exploring parties, etc. The walker does not need a large territory. When you get into a railway car you want a continent, the man in his carriage requires a township; but a walker like Thoreau finds as much and more along the shores of Walden Pond. The former, as it were, has merely time to glance at the headings of the chapters, while the latter need not miss a line, and Thoreau reads between the lines. Then the walker has the privilege of the fields, the woods, the hills, the byways. The apples by the roadside are for him, and the berries, and the spring of water, and the friendly shelter; and if the weather is cold, he eats the frost grapes and the persimmons, or even the white-meated turnip, snatched from the field he passed through, with incredible relish. 
Afoot and in the open road, one has a fair start in life at last. There is no hindrance now. Let him put his best foot forward. He is on the broadest human plane. This is on the level of all the great laws and heroic deeds. From this platform he is eligible to any good fortune. He was sighing for the golden age; let him walk to it. Every step brings him nearer. The youth of the world is but a few days' journey distant. Indeed, I know persons who think they have walked back to that fresh aforetime of a single bright Sunday in autumn or early spring. Before noon they felt its airs upon their cheeks, and by nightfall, on the banks of some quiet stream, or along some path in the wood, or on some hilltop, aver they have heard the voices and felt the wonder and the mystery that so enchanted the early races of men.

I think if I could walk through a country, I should not only see many things and have adventures that I should otherwise miss, but that I should come into relations with that country at first hand, and with the men and women in it, in a way that would afford the deepest satisfaction. Hence I envy the good fortune of all walkers, and feel like joining myself to every tramp that comes along. I am jealous of the clergyman I read about the other day, who footed it from Edinburgh to London, as poor Effie Deans did, carrying her shoes in her hand most of the way, and over the ground that rugged 


\section{THE EXHILARATIONS OF THE ROAD 31}

Ben Jonson strode, larking it to Scotland, so long ago. I read with longing of the pedestrian feats of college youths, so gay and light-hearted, with their coarse shoes on their feet and their knapsacks on their backs. It would have been a good draught of the rugged cup to have walked with Wilson the ornithologist, deserted by his companions, from Niagara to Philadelphia through the snows of winter. I almost wish that $I$ had been born to the career of a German mechanic, that I might have had that delicious adventurous year of wandering over my country before I settled down to work. I think how much richer and firmer-grained life would be to me if I could journey afoot through Florida and Texas, or follow the windings of the Platte or the Yellowstone, or stroll through Oregon, or browse for a season about Canada. In the bright, inspiring days of autumn I only want the time and the companion to walk back to the natal spot, the family nest, across two States and into the mountains of a third.XWhat adventures we would have by the way, what hard pulls, what prospects from hills, what spectacles we would behold of night and day, what passages with dogs, what glances, what peeps into windows, what characters we should fall in with, and how seasoned and hardy we should arrive at our destination!

For companion I should want a veteran of the war! Those marches put something into him I 
like. Even at this distance his mettle is but little softened. As soon as he gets warmed up, it all comes back to him. He catches your step and away you go, a gay, adventurous, half-predatory couple. How quickly he falls into the old ways of jest and anecdote and song! You may have known him for years without having heard him hum an air, or more than casually revert to the subject of his experience during the war. You have even questioned and cross-questioned him without firing the train you wished. But get him out on a vacation tramp, and you can walk it all out of him. By the camp-fire at night, or swinging along the streams by day, song, anecdote, adventure, come to the surface, and you wonder how your companion has kept silent so long.

It is another proof of how walking brings out the true character of a man. The devil never yet asked his victims to take a walk with him. You will not be long in finding your companion out. All disguises will fall away from him. As his pores open his character is laid bare. His deepest and most private self will come to the top. It matters little with whom you ride, so he be not a pickpocket; for both of you will, very likely, settle down closer and firmer in your reserve, shaken down like a measure of corn by the jolting as the journey proceeds. But walking is a more vital copartnership; the relation is a closer and more sympathetic one, and you do 


\section{THE EXHILARATIONS OF THE ROAD 33}

not feel like walking ten paces with a stranger without speaking to him.

Hence the fastidiousness of the professional walker in choosing or admitting a companion, and hence the truth of a remark of Emerson, that you will generally fare better to take your dog than to invite your neighbor. Your cur-dog is a true pedestrian, and your neighbor is very likely a small politician. The dog enters thoroughly into the spirit of the enterprise; he is not indifferent or preoccupied; he is constantly sniffing adventure, laps at every spring, looks upon every field and wood as a new world to be explored, is ever on some fresh trail, knows something important will happen a little farther on, gazes with the true wonder-seeing eyes, whatever the spot or whatever the road finds it good to be there, - in short, is just that happy, delicious, excursive vagabond that touches one at so many points, and whose human prototype in a companion robs miles and leagues of half their power to fatigue.

Persons who find themselves spent in a short walk to the market or the post-office, or to do a little shopping, wonder how it is that their pedestrian friends can compass so many weary miles and not fall down from sheer exhaustion; ignorant of the fact that the walker is a kind of projectile that drops far or near according to the expansive force of the motive that set it in motion, and that it is easy enough to regulate the charge according to the dis- 


\section{4 THE EXHILARATIONS OF THE ROAD}

tance to be traversed.X If I am loaded to carry only one mile and am compelled to walk three, I generally feel more fatigue than if $I$ had walked six under the proper impetus of preadjusted resolution. In other words, the will or corporeal mainspring, whatever it be, is capable of being wound up to different degrees of tension, so that one may walk all day nearly as easy as half that time, if he is prepared beforehand. He knows his task, and he measures and distributes his powers accordingly. It is for this reason that an unknown road is always a long road. We cannot cast the mental eye along it and see the end from the beginning. We are fighting in the dark, and cannot take the measure of our foe. Every step must be preordained and provided for in the mind. Hence also the fact that to vanquish one mile in the woods seems equal to compassing three in the open country. The furlongs are ambushed, and we magnify them.

Then, again, how annoying to be told it is only five miles to the next place when it is really eight or ten! We fall short nearly half the distance, and are compelled to urge and roll the spent ball the rest of the way. In such a case walking degenerates from a fine art to a mechanic art; we walk merely; to get over the ground becomes the one serious and engrossing thought; whereas success in walking is not to let your right foot know what your left foot doeth. Your heart must furnish such 


\section{THE EXHILARATIONS OF THE ROAD}

music that in keeping time to it your feet will carry you around the globe without knowing it. The walker I would describe takes no note of distance; his walk is a sally, a bonmot, an unspoken jeu d'esprit; the ground is his butt, his provocation; it furnishes him the resistance his body craves; he rebounds upon it, he glances off and returns again, and uses it gayly as his tool.

I do not think I exaggerate the importance or the charms of pedestrianism, or our need as a people to cultivate the art. I think it would tend to soften the national manners, to teach us the meaning of leisure, to acquaint us with the charms of the open air, to strengthen and foster the tie between the race and the land. No one else looks out upon the world so kindly and charitably as the pedestrian; no one else gives and takes so much from the country he passes through. Next to the laborer in the fields, the walker holds the closest relation to the soil; and he holds a closer and more vital relation to nature because he is freer and his mind more at leisure.

Man takes root at his feet, and at best he is no more than a potted plant in his house or carriage till he has established communication with the soil by the loving and magnetic touch of his soles to it. Then the tie of association is born; then spring those invisible fibres and rootlets through which character comes to smack of the soil, and which 
make a man kindred to the spot of earth he inhabits.

The roads and paths you have walked along in summer and winter weather, the fields and hills which you have looked upon in lightness and gladness of heart, where fresh thoughts have come into your mind, or some noble prospect has opened before you, and especially the quiet ways where you have walked in sweet converse with your friend, pausing under the trees, drinking at the spring, henceforth they are not the same; a new charm is added; those thoughts spring there perennial, your friend walks there forever.

We have produced some good walkers and saunterers, and some noted climbers; but as a staple recreation, as a daily practice, the mass of the people dislike and despise walking. Thoreau said he was a good horse, but a poor roadster. I chant the virtues of the roadster as well. I sing of the sweetness of gravel, good sharp quartz-grit. It is the proper condiment for the sterner seasons, and many a human gizzard would be cured of half its ills by a suitable daily allowance of it. I think Thoreau himself would have profited immensely by it. His diet was too exclusively vegetable. A man cannot live on grass alone. If one has been a lotus-eater all summer, he must turn gravel-eater in the fall and winter. Those who have tried it know that gravel possesses an equal though an opposite charm. 


\section{THE EXHILARATIONS OF THE ROAD 37}

It spurs to action. The foot tastes it and henceforth rests not. The joy of moving and surmounting, of attrition and progression, the thirst for space, for miles and leagues of distance, for sights and prospects, to cross mountains and thread rivers, and defy frost, heat, snow, danger, difficulties, seizes it; and from that day forth its possessor is enrolled in the noble army of walkers. 


\section{BIRD LIFE IN AN OLD APPLE-TREE ${ }^{1}$}

TEAR my study there used to stand several old 1 apple-trees that bore fair crops of apples, but better crops of birds. Every year these old trees were the scenes of bird incidents and bird histories that were a source of much interest and amusement. Young trees may be the best for apples, but old trees are sure to bear the most birds. If they are very decrepit, and full of dead and hollow branches, they will bear birds in winter as well as summer. The downy woodpecker wants no better place than the brittle, dozy trunk of an apple-tree in which to excavate his winter home. My old apple-trees are all down but one, and this one is probably an octogenarian, and $I$ am afraid cannot stand another winter. Its body is a mere shell not much over one inch thick, the heart and main interior structure having turned to black mould long ago. An old tree, unlike an old person, as long as it lives at all, always has a young streak, or rather ring, in it. It wears a girdle of perpetual youth.

My old tree has never yet failed to yield me a bushel or more of gillyflowers, and it has turned out

1 From Riverby. 


\section{BIRD LIFE IN AN OLD APPLE-TREE}

at least a dozen broods of the great crested flycatcher, and robins and bluebirds in proportion. It carries up one large decayed trunk, which some one sawed off at the top before my time, and in this a downy woodpecker is now, January 12, making a home. Several years ago, a downy woodpecker excavated a retreat in this branch, which the following season was appropriated by the bluebirds, and has been occupied by them nearly every season since. When the bluebirds first examined the cavity in the spring, I suppose they did not find the woodpecker at home, as he is a pretty early riser.

I happened to be passing near the tree when, on again surveying the premises one afternoon, they found him in. The male bluebird was very angry, and I suppose looked upon the innocent downy as an intruder. He seized on him, and the two fell to the ground, the speckled woodpecker quite covered by the blue coat of his antagonist. Downy screamed vigorously, and got away as soon as he could, but not till the bluebird had tweaked out a feather or two. He is evidently no fighter, though one would think that a bird that had an instrument with which it could drill a hole into a tree could defend itself against the soft-billed bluebird.

Two seasons the English sparrows ejected the bluebirds and established themselves in it, but were in turn ejected by me, their furniture of hens' feathers and straws pitched out, and the bluebirds 


\section{BIRD LIFE IN AN OLD APPLE-TREE}

invited to return, which later in the season they did.

The new cavity which downy is now drilling is just above the old one and near the top of the stub. Its wells are usually sunk to a depth of six or eight inches, but in the present case it cannot be sunk more than four inches without breaking through into the old cavity. Downy seems to have considered the situation, and is proceeding cautiously. As she passed last night in her new quarters, I am inclined to think it is about finished, and there must be at least one inch of wood beneath her. She worked vigorously the greater part of the day, her yellow chips strewing the snow beneath. I paused several times to observe her proceedings. After her chips accumulate, she stops her drilling and throws them out. This she does with her beak, shaking them out very rapidly with a flirt of her head. She did not disappear from sight each time to load her beak, but withdrew her head, and appeared to seize the fragments as if from her feet. If she had had a companion, I should have thought he was handing them up to her from the bottom of the cavity. Maybe she had them piled up near the doorway.

The woodpeckers, both the hairy and the downy, usually excavate these winter retreats in the fall. They pass the nights and the stormy days in them. So far as I have observed, they do not use them as nesting-places the following season. Last night 
when I rapped on the trunk of the old apple-tree near sundown, downy put out her head with a surprised and inquiring look, and then withdrew it again as I passed on.

I have spoken of the broods of the great crested flycatchers that have been reared in the old appletree. This is by no means a common bird, and as it destroys many noxious insects, I look upon it with a friendly eye, though it is the most uncouth and unmusical of the flycatchers. Indeed, among the other birds of the garden and orchard it seems quite like a barbarian. It has a harsh, froglike scream, form and manners to suit, and is clad in a suit of butternut brown. It seeks a cast-off snakeskin to weave into its nest, and not finding one, will take an onion skin, a piece of oiled paper, or large fish scales. It builds in a cavity in a tree, rears one brood, and is off early in the season. I never see or hear it after August 1.

A pair have built in a large, hollow limb in my old apple-tree for many years. Whether it is the same pair or not, I do not know. Probably it is, or else some of their descendants. I looked into the cavity one day while the mother bird was upon the nest, but before she had laid any eggs. A sudden explosive sound came up out of the dark depths of the limb, much like that made by an alarmed cat. It made me jerk my head back, when out came the bird and hurried off. For several days I saw no 


\section{BIRD LIFE IN AN OLD APPLE-TREE}

more of the pair, and feared they had deserted the spot. But they had not; they were only more sly than usual. I soon discovered an egg in the nest, and then another and another.

One day, as I stood near by, a male bluebird came along with his mate, prospecting for a spot for a second nest. He alighted at the entrance of this hole and peeped in. Instantly the flycatcher was upon him. The blue was enveloped by the butternut brown. The two fell to the ground, where the bluebird got away, and in a moment more came back and looked in the hole again, as much as to say, "I will look into that hole now at all hazards." The barbarian made a dash for him again, but he was now on his guard and avoided her.

Not long after, the bluebirds decided to occupy the old cavity of the downy woodpecker from which I had earlier in the season expelled the English sparrows. After they had established themselves here, a kind of border war broke out between the male bluebird and the flycatchers, and was kept up for weeks. The bluebird is very jealous and very bold. He will not even tolerate a house wren in the vicinity of his nest. Every bird that builds in a cavity he looks upon as his natural rival and enemy. The flycatchers did not seek any quarrel with him as long as he kept to his own domicile, but he could not tolerate them in the same tree. It was a pretty sight to see this little blue-coat charging the 


\section{BIRD LIFE IN AN OLD APPLE-TREE}

butternut through the trees. The beak of the latter would click like a gunlock, and its harsh, savage voice was full of anger, but the bluebird never flinched, and was always ready to renew the fight.

The English sparrow will sometimes worst the bluebird by getting possession of the box or cavity ahead of him. Once inside, the sparrow ean hold the fort, and the bluebird will soon give up the siege; but in a fair field and no favor, the native bird will quickly rout the foreigner.

Speaking of birds that build in cavities reminds me of a curious trait the high-hole has developed in my vicinity, one which I have never noticed or heard of elsewhere. It drills into buildings and steeples and telegraph poles, and in some instances makes itself a serious nuisance. One season the large imitation Greek columns of an unoccupied old-fashioned summer residence near me were badly marred by them. The bird bored into one column, and finding the cavity - a foot or more across - not just what it was looking for, cut into another one, and into still another. Then he bored into the ice-house on the premises, and in the sawdust filling between the outer and inner sheathing found a place to his liking. One bird seemed like a monomaniac, and drilled holes up and down and right and left, as if possessed of an evil spirit. It is quite probable that if a high-hole or other woodpecker should go crazy, it would take to just this sort of thing, drilling into 


\section{BIRD LIFE IN AN OLD APPLE-TREE}

seasoned timber till it used its strength up. The one I refer to would cut through a dry hemlock board in a very short time, making the slivers fly. The sound was like that of a carpenter's hammer. It may have been that he was an unmated bird, a bachelor, whose suit had not prospered that season, and who was giving vent to his outraged instincts in drilling these mock nesting-places. 


\section{BIRD COURTSHIP 1}

THERE is something about the matchmaking of 1 birds that is not easily penetrated. The jealousies and rivalries of the males and of the females are easily understood, - they are quite human; but those sudden rushes of several males, some of them already mated, after one female, with squeals and screams and a great clatter of wings, - what does it mean? 'There is nothing human about that, unless it be illustrative of a trait that has at times cropped out in the earlier races, and which is still seen among the Eskimos, where the male carries off the female by force. But in these sudden sallies among the birds, the female, so far as I have observed, is never carried off. One may see half a dozen English sparrows engaged in what at first glance appears to be a general mêlée in the gutter or on the sidewalk; but if you look more closely, you will see a single female in the midst of the mass, beating off the males, who, with plumage puffed out and screaming and chattering, are all making a set at her. She strikes right and left, and seems to be equally displeased with them all. But her anger may be all put on, and she may be giving the wink all the time to her favorite.

1 From Riverby. 
The Eskimo maiden is said by Doctor Nansen to resist stoutly being carried off even by the man she is desperately in love with.

In the latter half of April, we pass through what I call the "robin racket," - trains of three or four birds rushing pell-mell over the lawn and fetching up in a tree or bush, or occasionally upon the ground, all piping and sereaming at the top of their voices, but whether in mirth or anger it is hard to tell. The nucleus of the train is a female. One cannot see that the males in pursuit of her are rivals; it seems rather as if they had united to hustle her out of the place. But somehow the matches are no doubt made and sealed during these mad rushes. Maybe the female shouts out to her suitors, "Who touches me first wins," and away she scurries like an arrow. The males shout out, "Agreed!" and away they go in pursuit, each trying to outdo the other. 'The game is a brief one. Before one can get the clew to it, the party has dispersed.

Earlier in the season the pretty sparring of the males is the chief feature. You may see two robins apparently taking a walk or a run together over the sward or along the road; only first one bird runs, and then the other. They keep a few feet apart, stand very erect, and the course of each describes the segment of an arc about the other, thus:-

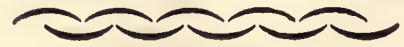


How courtly and deferential their manners toward each other are! often they pipe a shrill, fine strain, audible only a few yards away. Then, in a twinkling, one makes a spring and they are beak to beak, and claw to claw, as they rise up a few feet into the air. But usually no blow is delivered; not a feather is ruffled; each, I suppose, finds the guard of the other perfect. Then they settle down upon the ground again, and go through with the same running challenge as before. How their breasts glow in the strong April sunlight; how perk and military the bearing of each! Often they will run about each other in this way for many rods. After a week or so the males seem to have fought all their duels, when the rush and racket $I$ have already described begin.

The bluebird wins his mate by the ardor of his attentions and the sincerity of his compliments, and by finding a house ready built which cannot be surpassed. The male bluebird is usually here several days before the female, and he sounds forth his note as loudly and eloquently as he can till she appears. On her appearance he flies at once to the box or tree cavity upon which he has had his eye, and, as he looks into it, calls and warbles in his most persuasive tones. The female at such times is always shy and backward, and the contrast in the manners of the two birds is as striking as the contrast in their colors. The male is brilliant and ardent; the female is dim and retiring, not to say indifferent. She may take a 
hasty peep into the hole in the box or tree and then fly away, uttering a lonesome, homesick note. Only by a wooing of many days is she to be fully won.

The past April I was witness one Sunday morning to the jealousies that may rage in these little brown breasts. A pair of bluebirds had apparently mated and decided to occupy a woodpecker's lodge in the limb of an old apple-tree near my study. But that morning another male appeared on the scene, and was bent on cutting the first male out, and carrying off his bride. I happened to be near by when the two birds came into collision. They fell to the grass, and kept their grip upon each other for half a minute. Then they separated, and the first up flew to the hole and called fondly to the female. This was too much for the other male, and they clinched again and fell to the ground as before. There they lay upon the grass, blue and brown intermingled. But not a feather was tweaked out, or even disturbed, that I could see. They simply held each other down. Then they separated again, and again rushed upon each other. The battle raged for about fifteen minutes, when one of the males - which one, of course, I could not tell - withdrew and flew to a box under the eaves of the study, and exerted all the eloquence he possessed to induce the female to come to him there. How he warbled and called, and lifted his wings and flew to the entrance to the box and called again! The female was evidently strongly attracted; 
she would respond and fly about halfway to an apple-tree, and look toward him. The other male, in the mean time, did his best to persuade her to cast her lot with him. He followed her to the tree toward his rival, and then flew back to the nest and spread his plumage and called and warbled, oh, so confidently, so fondly, so reassuringly! When the female would return and peep into the hole in the tree, what fine, joyous notes he would utter! then he would look in and twinkle his wings, and say something his rival could not hear. This vocal and pantomimic contest went on for a long time. The female was evidently greatly shaken in her allegiance to the male in the old apple-tree. In less than an - hour another female responded to the male who had sought the eaves of the study, and flew with him to the box. Whether this was their first meeting or not I do not know, but it was clear enough that the heart of the male was fixed upon the bride of his rival. He would devote himself a moment to the new-comer, and then turn toward the old apple-tree and call and lift his wings; then, apparently admonished by the bird near him, he would turn again to her and induce her to look into the box, and would warble fondly; then up on a higher branch again, with his attention directed toward his first love, between whom and himself salutations seemed constantly passing. This little play went on for some time, when the two females came into collision, and 
fell to the ground tweaking each other spitefully. Then the four birds drifted away from me down into the vineyard, where the males closed with each other again and fell to the plowed ground and lay there a surprisingly long time, nearly two minutes, as we calculated. Their wings were outspread, and their forms were indistinguishable. They tugged at each other most doggedly; one or the other brown breast was generally turned up, partly overlaid by a blue coat. They were determined to make a finish of it this time, but which got the better of the fight I could not tell. But it was the last battle; they finally separated, neither, apparently, any the worse for the encounter. The females fought two more rounds, the males looking on and warbling approvingly when they separated, and the two pairs drifted away in different directions. The next day they were about the box and tree again, and seemed to have definitely settled matters. Who won and who lost I do not know, but two pairs of bluebirds have since been very busy and very happy about the two nesting-places. One of the males I recognize as a bird that appeared early in March; I recognize him from one peculiar note in the midst of his warble, a note that suggests a whistle.

The matchmaking of the high-holes, which often comes under my observation, is in marked contrast to that of the robins and the bluebirds. There does not appear to be any anger or any blows. The male 
or two males will alight on a limb in front of the female, and go through with a series of bowings and scrapings that are truly comical. He spreads his tail, he puffs out his breast, he throws back his head, and then bends his body to the right and to the left, uttering all the while a curious musical hiccough. The female confronts him unmoved, but whether her attitude is critical or defensive, I cannot tell. Presently she flies away, followed by her suitor or suitors, and the little comedy is enacted on another stump or tree. Among all the woodpeckers the drum plays an important part in the matchmaking. The male takes up his stand on a dry, resonant limb, or on the ridgeboard of a building, and beats the loudest call he is capable of. The downy woodpecker usually has a particular branch to which he resorts for advertising his matrimonial wants. A favorite drum of the high-holes about me is a hollow wooden tube, a section of a pump, which stands as a bird-box upon my summer-house. It is a good instrument; its tone is sharp and clear. A high-hole alights upon it, and sends forth a rattle that can be heard a long way off. Then he lifts up his head and utters that long April call, Wick, wick, wick, wick. Then he drums again. If the female does not find him, it is not because he does not make noise enough. But his sounds are all welcome to the ear. They are simple and primitive, and voice well a certain sentiment of the April days. As I 
write these lines I hear through the half-open door his call come up from a distant field. Then I hear the steady hammering of one that has been for three days trying to penetrate the weather boarding of the big icehouse by the river, and to reach the sawdust filling for a nesting-place.

Among our familiar birds the matchmaking of none other is quite so pretty as that of the goldfinch. The goldfinches stay with us in loose flocks and clad in a dull-olive suit throughout the winter. In May the males begin to put on their bright summer plumage. This is the result of a kind of superficial moulting. Their feathers are not shed, but their dusky covering or overalls are cast off. When the process is only partly completed, the bird has a smutty, unpresentable appearance. But we seldom see them at such times. They seem to retire from society. When the change is complete, and the males have got their bright uniforms of yellow and black, the courting begins. All the goldfinches of a neighborhood collect together and hold a sort of musical festival. To the number of many dozens they may be seen in some large tree, all singing and calling in the most joyous and vivacious manner. The males sing, and the females chirp and call. Whether there is actual competition on a trial of musical abilities of the males before the females or not, I do not know. The best of feeling seems to pervade the company; there is no sign of quarreling or fight- 
ing; "all goes merry as a marriage bell," and the matches seem actually to be made during these musical picnics. Before May is passed the birds are seen in couples, and in June housekeeping usually begins. This I call the ideal of love-making among birds, and is in striking contrast to the squabbles and jealousies of most of our songsters.

I have known the goldfinches to keep up this musical and love-making festival through three consecutive days of a cold northeast rainstorm. Bedraggled, but ardent and happy, the birds were not to be dispersed by wind or weather.

All the woodpeckers, so far as I have observed, drum up their mates; the male advertises his wants by hammering upon a dry, resonant limb, when in due time the female approaches and is duly courted and won. The drumming of the ruffed grouse is for the same purpose; the female hears, concludes to take a walk that way, approaches timidly, is seen and admired, and the match is made. That the male accepts the first female that offers herself is probable. Among all the birds the choice, the selection, seems to belong to the female. The males court promiscuously; the females choose discreetly. The grouse, unlike the woodpecker, always carries his drum with him, which is his own proud breast; yet, if undisturbed, he selects some particular log or rock in the woods from which to sound forth his willingness to wed. What determines the choice of 
the female it would be hard to say. Among songbirds, it is probably the best songster, or the one whose voice suits her taste best. Among birds of bright plumage, it is probably the gayest dress; among the drummers, she is doubtless drawn by some quality of the sound. Our ears and eyes are too coarse to note any differences in these things, but doubtless the birds themselves note differences.

Birds show many more human traits than do quadrupeds. That they actually fall in love admits of no doubt; that there is a period of courtship, during which the male uses all the arts he is capable of to win his mate, is equally certain; that there are jealousies and rivalries, and that the peace of families is often rudely disturbed by outside males or females is a common observation. The females, when they come to blows, fight much more spitefully and recklessly than do the males. One species of bird has been known to care for the young of another species which had been made orphans. The male turkey will sometimes cover the eggs of his mate and hatch and rear the brood alone. Altogether, birds often present some marked resemblances in their actions to men, when love is the motive.

Mrs. Martin, in her "Home Life on an Ostrich Farm," relates this curious incident: -

"One undutiful hen - having apparently imbibed advanced notions - absolutely refused to sit at all, and the poor husband, determined not to be 
disappointed of his little family, did all the work himself, sitting bravely and patiently day and night, though nearly dead with exhaustion, till the chicks were hatched out. The next time this pair of birds had a nest, the cock's mind was firmly made up that he would stand no more nonsense. He fought the hen [kicked her], giving her so severe a thrashing that she was all but killed, and this Petruchio-like treatment had the desired effect, for the wife never again rebelled, but sat submissively."

In the case of another pair of ostriches of which Mrs. Martin tells, the female was accidentally killed, when the male mourned her loss for over two years, and would not look at another female. He wandered up and down, up and down, the length of his camp, utterly disconsolate. At last he mated again with a most magnificent hen, who ruled him tyrannically; he became the most hen-pecked, or rather hen-kicked, of husbands. 


\section{THE SNOW-WALKERS ${ }^{1}$}

WHE track of the red squirrel may be known by 1 its smaller size. He is more common and less dignified than the gray, and oftener guilty of petty larceny about the barns and grain-fields. He is most abundant in old barkpeelings, and low, dilapidated hemlocks, from which he makes excursions to the fields and orchards, spinning along the tops of the fences, which afford not only convenient lines of communication, but a safe retreat if danger threatens. He loves to linger about the orchard; and, sitting upright on the topmost stone in the wall, or on the tallest stake in the fence, chipping up an apple for the seeds, his tail conforming to the curve of his back, his paws shifting and turning the apple, he is a pretty sight, and his bright, pert appearance atones for all the mischief he does. At home, in the woods, he is the most frolicsome and loquacious. The appearance of anything unusual, if, after contemplating it a moment, he concludes it not dangerous, excites his umbounded mirth and ridicule, and he snickers and chatters, hardly able to contain himself; now darting up the trunk of a tree and squealing in derision, then hopping into position on

1 An excerpt from a chapter in Winter Sunshine. 
a limb and dancing to the music of his own cackle, and all for your special benefit.

There is something very human in this apparent mirth and mockery of the squirrels. It seems to be a sort of ironical laughter, and implies self-conscious pride and exultation in the laugher. "What a ridiculous thing you are, to be sure!" he seems to say; "how clumsy and awkward, and what a poor show for a tail! Look at me, look at me!" - and he capers about in his best style. Again, he would seem to tease you and provoke your attention; then suddenly assumes a tone of good-natured, childlike defiance and derision. That pretty little imp, the chipmunk, will sit on the stone above his den and defy you, as plainly as if he said so, to catch him before he can get into his hole if you can. You hurl a stone at him, and "No you did n't!" comes up from the depth of his retreat.

In February another track appears upon the snow, slender and delicate, about a third larger than that of the gray squirrel, indicating no haste or speed, but, on the contrary, denoting the most imperturbable ease and leisure, the footprints so close together that the trail appears like a chain of curiously carved links. Sir Mephitis mephitica, or, in plain English, the skunk, has awakened from his six weeks' nap, and come out into society again. He is a nocturnal traveler, very bold and impudent, coming quite up to the barn and outbuildings, and 
sometimes taking up his quarters for the season under the haymow. There is no such word as hurry in his dictionary, as you may see by his path upon the snow. He has a very sneaking, insinuating way, and goes creeping about the fields and woods, never once in a perceptible degree altering his gait, and, if a fence crosses his course, steers for a break or opening to avoid climbing. $\mathrm{He}$ is too indolent even to dig his own hole, but appropriates that of a woodchuck, or hunts out a crevice in the rocks, from which he extends his rambling in all directions, preferring damp, thawy weather. He has very little discretion or cunning, and holds a trap in utter contempt, stepping into it as soon as beside it, relying implicitly for defense against all forms of danger upon the unsavory punishment he is capable of inflicting. He is quite indifferent to both man and beast, and will not hurry himself to get out of the way of either. Walking through the summer fields at twilight, I have come near stepping upon him, and was much the more disturbed of the two. When attacked in the open fields he confounds the plans of his enemies by the unheard-of tactics of exposing his rear rather than his front. "Come if you dare," he says, and his attitude makes even the farm-dog pause. After a few encounters of this kind, and if you entertain the usual hostility towards him, your mode of attack will speedily resolve itself into moving about him in a circle, the 


\section{THE SNOW-WALKERS}

radius of which will be the exact distance at which you can hurl a stone with accuracy and effect.

He has a secret to keep and knows it, and is careful not to betray himself until he can do so with the most telling effect. I have known him to preserve his serenity even when caught in a steel trap, and look the very picture of injured innocence, manœuvring carefully and deliberately to extricate his foot from the grasp of the naughty jaws. Do not by any means take pity on him, and lend a helping hand!

How pretty his face and head! How fine and delicate his teeth, like a weasel's or cat's! When about a third grown, he looks so well that one covets him for a pet. He is quite precocious, however, and capable, even at this tender age, of making a very strong appeal to your sense of smell.

No animal is more cleanly in its habits than he. He is not an awkward boy who cuts his own face with his whip; and neither his flesh nor his fur hints the weapon with which he is armed. The most silent creature known to me, he makes no sound, so far as I have observed, save a diffuse, impatient noise, like that produced by beating your hand with a whisk-broom, when the farm-dog has discovered his retreat in the stone fence. He renders himself obnoxious to the farmer by his partiality for hens' eggs and young poultry. He is a confirmed epicure, and at plundering hen-roosts an 
expert. Not the full-grown fowls are his victims, but the youngest and most tender. At night Mother Hen receives under her maternal wings a dozen newly hatched chickens, and with much pride and satisfaction feels them all safely tucked away in her feathers. In the morning she is walking about disconsolately, attended by only two or three of all that pretty brood. What has happened? Where are they gone? That pickpocket, Sir Mephitis, could solve the mystery. Quietly has he approached, under cover of darkness, and one by one relieved her of her precious charge. Look closely and you will see their little yellow legs and beaks, or part of a mangled form, lying about on the ground. Or, before the hen has hatched, he may find her out, and, by the same sleight of hand, remove every egg, leaving only the empty blood-stained shells to witness against him. The birds, especially the groundbuilders, suffer in like manner from his plundering propensities.

The secretion upon which he relies for defense, and which is the chief source of his unpopularity, while it affords good reasons against cultivating him as a pet, and mars his attractiveness as game, is by no means the greatest indignity that can be offered to a nose. It is a rank, living smell, and has none of the sickening qualities of disease or putrefaction. Indeed, I think a good smeller will enjoy its most refined intensity. It approaches the sublime, and 


\section{THE SNOW-WALKERS}

makes the nose tingle. It is tonic and bracing, and, I can readily believe, has rare medicinal qualities. I do not recommend its use as eyewater, though an old farmer assures me it has undoubted virtues when thus applied. Hearing, one night, a disturbance among his hens, he rushed suddenly out to catch the thief, when Sir Mephitis, taken by surprise, and no doubt much annoyed at being interrupted, discharged the vials of his wrath full in the farmer's face, and with such admirable effect that, for a few moments, he was completely blinded, and powerless to revenge himself upon the rogue, who embraced the opportunity to make good his escape; but he declared that afterwards his eyes felt as if purged by fire, and his sight was much clearer. 


\section{AMONG THE WILD FLOWERS ${ }^{1}$}

NE sometimes seems to discover a familiar wild flower anew by coming upon it in some peculiar and striking situation. Our columbine is at all times and in all places one of the most exquisitely beautiful of flowers; yet one spring day, when I saw it growing out of a small seam on the face of a great lichen-covered wall of rock, where no soil or mould was visible, - a jet of foliage and color shooting out of a black line on the face of a perpendicular mountain wall and rising up like a tiny fountain, its drops turning to flame-colored jewels that hung and danced in the air against the gray rocky surface, - its beauty became something magical and audacious. On little narrow shelves in the rocky wall the corydalis was blooming, and among the loose bowlders at its base the blood-root shone conspicuous, suggesting snow rather than anything more sanguine.

Certain flowers one makes special expeditions for every season. They are limited in their ranges, and must generally be sought for in particular haunts. How many excursions to the woods does the delicious trailing arbutus give rise to! How

1 An excerpt from a chapter in Riverby. 


\section{AMONG THE WILD FLOWERS}

can one let the spring go by without gathering it himself when it hides in the moss! There are arbutus days in one's calendar, days when the trailing flower fairly calls him to the woods. With me, they come the latter part of April. The grass is greening here and there on the moist slopes and by the spring runs; the first furrow has been struck by the farmer; the liver-leaf is in the height of its beauty, and the bright constellations of the bloodroot shine out here and there; one has had his first taste and his second taste of the spring and of the woods, and his tongue is sharpened rather than cloyed. Now he will take the most delicious and satisfying draught of all, the very essence and soul of the early season, of the tender brooding days, with all their prophecies and awakenings, in the handful of trailing arbutus which he gathers in his walk. At the mere thought of it, one sees the sunlight flooding the woods, smells the warm earthy odors which the heat liberates from beneath the dry leaves, hears the mellow bass of the first bumblebee,

"Rover of the underwoods,"

or the finer chord of the adventurous honey-bee seeking store for his empty comb. The arriving swallows twitter above the woods; the first chewink rustles the dry leaves; the northward-bound thrushes, the hermit and the gray-cheeked, flit here 
and there before you. The robin, the sparrow, and the bluebird are building their first nests, and the first shad are making their way slowly up the Hudson. Indeed, the season is fairly under way when the trailing arbutus comes. Now look out for troops of boys and girls going to the woods to gather it! and let them look out that in their greed they do not exterminate it. Within reach of our large towns, the choicer spring wild flowers are hunted mercilessly. Every fresh party from town raids them as if bent upon their destruction. One day, about ten miles from one of our Hudson River cities, there got into the train six young women loaded down with vast sheaves and bundles of trailing arbutus. Each one of them had enough for forty. They had apparently made a clean sweep of the woods. It was a pretty sight, - the pink and white of the girls and the pink and white of the flowers! and the car, too, was suddenly filled with perfume, - the breath of spring loaded the air; but I thought it a pity to ravish the woods in that way. The next party was probably equally greedy, and, because a handful was desirable, thought an armful proportionately so; till, by and by, the flower will be driven from those woods.

Another flower that one makes special excursions for is the pond-lily. The pond-lily is a star, and easily takes the first place among lilies; and the expeditions to her haunts, and the gathering her where 
she rocks upon the dark secluded waters of some pool or lakelet, are the crown and summit of the floral expeditions of summer. It is the expedition about which more things gather than almost any other: you want your boat, you want your lunch, you want your friend or friends with you. You are going to put in the greater part of the day; you are going to picnic in the woods, and indulge in a "green thought in a green shade." When my friend and I go for pond-lilies, we have to traverse a distance of three miles with our boat in a wagon. The road is what is called a "back road," and leads through woods most of the way. Black Pond, where the lilies grow, lies about one hundred feet higher than the Hudson, from which it is separated by a range of rather bold wooded heights, one of which might well be called Mount Hymettus, for I have found a great deal of wild honey in the forest that covers it. The stream which flows out of the pond takes a northward course for two or three miles, till it finds an opening through the rocky hills, when it makes rapidly for the Hudson. Its career all the way from the lake is a series of alternating pools and cascades. Now a long, deep, level stretch, where the perch and the bass and the pickerel lurk, and where the willow-herb and the royal osmunda fern line the shores; then a sudden leap of eight, ten, or fifteen feet down rocks to another level stretch, where the water again loiters and suns 
itself; and so on through its adventurous course till the hills are cleared and the river is in sight. Our road leads us along this stream, across its rude bridges, through dark hemlock and pine woods, under gray, rocky walls, now past a black pool, then within sight or hearing of a foaming rapid or fall, till we strike the outlet of the long level that leads to the lake. In this we launch our boat and paddle slowly upward over its dark surface, now pushing our way through half-submerged treetops, then ducking under the trunk of an overturned tree which bridges the stream and makes a convenient way for the squirrels and wood-mice, or else forcing the boat over it when it is sunk a few inches below the surface. We are traversing what was once a continuation of the lake; the forest floor is as level as the water and but a few inches above it, even in summer; it sweeps back a half mile or more, densely covered with black ash, red miple, and other deciduous trees, to the foot of the rocky hills which shut us in. What glimpses we get, as we steal along, into the heart of the rank, dense, silent woods! I carry in my eye yet the vision I had, on one occasion, of a solitary meadow lily hanging like a fairy bell there at the end of a chance opening, where a ray of sunlight fell full upon it, and brought out its brilliant orange against the dark green background. It appeared to be the only bit of bright color in all the woods. Then the song of a single 


\section{AMONG THE WILD FLOWERS}

hermit thrush immediately after did even more for the ear than the lily did for the eye. Presently the swamp sparrow, one of the rarest of the sparrows, was seen and heard; and that nest there in a small bough a few feet over the water proves to be hers, - in appearance a ground-bird's nest in a bough, with the same four speckled eggs. As we come in sight of the lilies, where they cover the water at the outlet of the lake, a brisk gust of wind, as if it had been waiting to surprise us, sweeps down and causes every leaf to leap from the water and show its pink under side. Was it a fluttering of hundreds of wings, or the clapping of a multitude of hands? But there rocked the lilies with their golden hearts open to the sun, and their tender white petals as fresh as crystals of snow. What a queenly flower, indeed, the type of unsullied purity and sweetness! Its root, like a black, corrugated, ugly reptile, clinging to the slime, but its flower in purity and whiteness like a star. There is something very pretty in the closed bud making its way up through the water to meet the sun; and there is something touching in the flower closing itself up again after its brief career, and slowly burying itself beneath the dark wave. One almost fancies a sad, regretful look in it as the stem draws it downward to mature its seed on the sunless bottom. The pondlily is a flower of the morning; it closes a little after noon; but after you have plucked it and carried it 
home, it still feels the call of the morning sun, and will open to him, if you give it a good chance. Coil their stems up in the grass on the lawn, where the sun's rays can reach them, and sprinkle them copiously. By the time you are ready for your morning walk, there they sit upon the moist grass, almost as charmingly as upon the wave.

Our more choice wild flowers, the rarer and finer spirits among them, please us by their individual beauty and charm; others, more coarse and common, delight us by mass and profusion; we regard not the one, but the many, as did Wordsworth his golden daffodils:-

"Ten thousand saw $I$ at a glance

Tossing their heads in sprightly dance."

Of such is the marsh marigold, giving a golden lining to many a dark, marshy place in the leafless April woods, or marking a little watercourse through a greening meadow with a broad line of new gold. One glances up from his walk, and his eye falls upon something like fixed and heaped-up sunshine there beneath the alders, or yonder in the freshening field. 


\section{THE DIVINE SOIL ${ }^{1}$.}

NE thing we may affirm about the universe it is logical; the conclusion always follows from the premises.

The lesson which life repeats and constantly enforces is "look under foot." You are always nearer the divine and the true sources of your power than you think. The lure of the distant and the difficult is deceptive. The great opportunity is where you are. Do not despise your own place and hour. Every place is under the stars, every place is the centre of the world. Stand in your own dooryard and you have eight thousand miles of solid ground beneath you, and all the sidereal splendors overhead. The morning and the evening stars are no more in the heavens and no more obedient to the celestial impulses than the lonely and timescarred world we inhabit. How the planet thrills and responds to the heavenly forces and occurrences we little know, but we get an inkling of it when we see the magnetic needle instantly affected by solar disturbances.

Look under foot. Gold and diamonds and all

1 An excerpt from a chapter in Leaf and Tendril. 
precious stones come out of the ground; they do not drop upon us from the stars, and our highest thoughts are in some way a transformation or a transmutation of the food we eat. The mean is the / divine if we make it so. The child surely learns that its father and mother are the Santa Claus that brought the gifts, though the discovery may bring pain; and the man learns to see providence in the great universal forces of nature, in the winds and the rain, in the soil underfoot and in the cloud overhead. What these forces in their orderly rounds do not bring him, he does not expect. The farmer hangs up his stocking in the way of empty bins and barns, and he knows well who or what must fill them. The Santa Claus of the merchant, the manufacturer, the inventor, is the forces and conditions all about us in every-day operation. When the lightning strikes your building or the trees on your lawn, you are at least reminded that you do not live in a corner outside of Jove's dominions, you are in the circuit of the great forces. If you are eligible to bad fortune where you stand, you are equally eligible to good fortune there. The young man who went West did well, but the young man who had the Western spirit and stayed at home did equally well. To evoke a spark of fire out of a flint with a bit of steel is the same thing as evoking beautiful thoughts from homely facts. How hard it is for us to see the heroic in an act of our neighbor! 


\section{THE DIVINE SOIL}

What a burden science took upon itself when it sought to explain the origin of man! Religion or theology takes a short cut and makes quick work of it by regarding man as the result of the special creative act of a supernatural Being. But science takes a long and tedious and hazardous way around through the lowest primordial forms of life. It seeks to trace his germ through the abyss of geologic time, where all is dim and mysterious, through countless cycles of waiting and preparation, where the slow, patient gods of evolution cherished it and passed it on, through the fetid carbon, through the birth and decay of continents, through countless interchanges and readjustments of sea and land, through the clash and warring of the cosmic forces, through good and evil report, through the fish and the reptile, through the ape and the orang, up to man - from the slime at the bottom of the primordial ocean up to Jesus of Nazareth. Surely one may say with Whitman,-

"Immense have been the preparations for me, Faithful and friendly the arms that have helped me."

It took about one hundred thousand feet of sedimentary rock, laid down through hundreds of millions of years in the bottom of the old scas, all probably the leavings of minute forms of life, to make a foundation upon which man could appear. 
His origin as revealed by science fills and appalls the imagination: as revealed by theology it simply baffles and dumfounds one. Science deepens the mystery while yet it gives the reason and the imagination something to go upon; it takes us beyond soundings, but not beyond the assurance that cause and effect are still continuous there beneath us. I like to think that man has traveled that long, adventurous road, that the whole creation has pulled

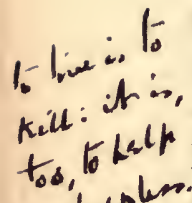
the listers. together to produce him. It is a road, of course, beset with pain and anguish, beset with ugly and repellent forms, beset with riot and slaughter; it leads through jungle and morass, through floods and cataclysms, through the hells of the Mesozoic and the Cenozoic periods, but it leads ever upward and onward.

The manward impulse in creation has doubtless been checked many times, but never lost; all forms conspired to further it, and it seemed to have taken the push and the aspiration out of each order as it passed on, dooming it henceforth to a round of life without change or hope of progress, leaving the fish to continue fish, the reptiles to contiaue reptiles, the apes to continue apes; it took all the heart and soul of each to feed and continue the central impulse that was to eventuate in man.

I fail to see why our religious brethren cannot find in this history or revelation as much room for creative energy, as large a factor of the mysterious and 
superhuman, as in the myth of Genesis. True it is that it fixes our attention upon this world and upon forces with which we are more or less familiar, but it implies an element or a power before which we stand helpless and dumb. What fathered this manimpulse, what launched this evolutionary process, what or who stamped upon the first protoplasm the aspiration to be man, and never let that aspiration sleep through all the tremendous changes of those incalculable geologic ages? What or who first planted the seed of the great biological tree, and determined all its branchings and the fruit it should bear? If you must have a God, either apart from or imminent in creation, it seems to me that there is as much need of one here as in the Mosaic cosmology. The final mystery cannot be cleared up. We can only drive it to cover. How the universe came to be what it is, and how man came to be man, who can tell us?

That somewhere in my line of descent was an ancestor that lived in trees and had powerful arms and weaker legs, that his line began in a creature that lived on the ground, and his in one that lived in the mud, or in the sea, and his, or its, sprang from a germ at the bottom of the sea, but deepens the mystery of the being that is now here and can look back and speculate over the course he has probably come; it only directs attention to ugly facts, to material things, to the every-day process 
of evolution, instead of to the far away, the un known, or the supernatural.

How the organic came to bud and grow from the inorganic, who knows? Yet it must have done so. We seem compelled to think of an ascending series from nebular matter up to the spirituality of man, each stage in the series resting upon or growing out of the one beneath it. Creation or development must be continuous. There are and can be no breaks. The inorganic is already endowed with chemical and molecular life. The whole universe is alive, and vibrates with impulses too fine for our dull senses; but in chemical affinity, in crystallization, in the persistence of force, in electricity, we catch glimpses of a kind of vitality that is preliminary to all other. I never see fire burn, or water flow, or the frost-mark on the pane, that I am not reminded of something as mysterious as life. How alive the flame seems, how alive the water, how marvclous the arborescent etchings of the frost! Is there a principle of fire? Is there a principle of crystallization? Just as much as there is a principle of life. The mind, in each case, seems to require something to lay. hold of as a cause. Why these wonderful star forms of the snowflake? Why these exact geometric forms of quartz crystals? The gulf between disorganized matter and the crystal seems to me as great as that between the organic and the inor- 


\section{THE DIVINE SOIL}

ganic. If we did not every day witness the passage, we could not believe it. The gulf between the crystal and the cell we have not seen cleared, and man has not yet been able to bridge it, and may never be, but it has been bridged, and I dare say without any more miracle than hourly goes on around us. The production of water from two invisible gases is a miracle to me. When water appeared (what made it appear?) and the first cloud floated across the blue sky, life was not far off, if it was not already there. Some morning in spring when the sun shone across the old Azoic hills, at some point where the land and sea met, life began - the first speck of protoplasm appeared. Call it the result of the throb or push of the creative energy that pervades all things, and whose action is continuous and not intermittent, since we are compelled to presuppose such energy to account for anything, even our own efforts to account for things. An ever active vital force pervades the universe, and is felt and seen in all things, from atomic attraction and repulsion up to wheeling suns and systems. The very processes of thought seem to require such premises to go upon. There is a reason for the universe as we find it, else man's reason is a delusion, and delusion itself is a meaningless term. The uncaused is unthinkable; thought can find neither beginning nor ending to the universe because it cannot find the primal cause. Can 
we think of a stick with only one end? We have to if we compass time in thought, or space, either.

So far as science can find out, sentience is a pro- . perty of matter which is evolved under certain conditions, and though science itself has not yet been able to reproduce these conditions, it still believes in the possibility. If life was not potential in the inorganic world, how is it possible to account for it? It is not a graft, it is more like a begetting. Nature does not work by prefixes and suffixes, but by unfolding and ever unfolding, or developing out of latent innate powers and possibilities; - an inward necessity always working, but never an external maker. It is no help to fancy that life may have been brought to the earth by a falling meteorite from some other sphere. How did life originate upon that other sphere? It must have started here as surely as fire started here. We feign that Prometheus stole the first, fire from heaven, but it sleeps here all about us, and can be evoked any time and anywhere. It sleeps in all forms of force. A falling avalanche of rocks turns to flame; the meteor in the air becomes a torch; 
the thunderbolt is a huge spark. So life, no doubt, slept in the inorganic, and was started by the reverse of friction, namely, by brooding.

When the earth becomes lifeless again, as it surely must in time, then the cycle will be repeated, a collision will develop new energy and new worlds, and out of this newness will again come life.

It is highly probable that a million years elapsed between the time when the ancestor of man began to assume the human form and the dawn of history. Try to think of that time and of the struggle of this creature upward; of the pain, the suffering, the low bestial life, the warrings, the defcats, the slow, infinitely slow gains, of his deadly enemies in other animals, of the repeated changes of climate of the northern hemisphere from subtropical to subarctic - the land at one time for thousands of years buried beneath an ice sheet a mile or more thick, followed by a cycle of years of almost tropical warmth even in Greenland - and all of this before man had yet got off of " all fours," and stood upright and began to make rude tools and rude shelters from the storms. The Tertiary period, early in which the first rude ancestor of man seems to have appeared, is less than one week of the great geologic year of the earth's history - a week of about five days. These days the geologists have named Eocene, Oligocene, Miocene, Pliocene, and Pleistocene, each one of these days covering, no 
doubt, a million years or more. The ancestor of man probably took on something like the human form on the third, or Miocene, day. The other and earlier fifty or more weeks of the great geologic year gradually saw the development of the simpler forms of life, till we reach the earliest mammals and reptiles in the Permian, about the forty-eighth or forty-ninth week of the great year. The laying down of the coal measures, Huxley thinks, must have taken six millions of years. Well, the Lord allowed himself enough time. Evidently he was in no hurry to see man cutting his fantastic tricks here upon the surface of the planet. A hundred million years, more or less, what of it? Did the globe have to ripen all those cycles upon cycles, like the apple upon the tree? bask in the sidereal currents, work and ferment in the sea of the hypothetical ether before the gross matter could evolve the higher forms of life? Probably every unicellular organism that lived and died in the old seas helped prepare the way for man, contributed something to the fund of vital energy of the globe upon which man was finally to draw.

How life has had to adjust itself to the great cosmic changes! The delays must have been incalculable. The periodic refrigeration of the northern hemisphere, which brought on the ice age several times during each one of the Eocene and Miocene days, must have delayed the development of life as we know it, enormously. 
From nebula to nebula - these are the hours struck by the clock of eternity : from the dissipation of the solar systems into nebular gas by their falling together to their condensation again into suns and worlds by the action of physical laws - thousands of millions of years in each hour, and the hours infinite in number. This is a hint of eternity. How many times, then, there must have been a world like this evolved in the course of this running down and winding up of the great clock, with beings like these we now behold! how many such worlds and such beings there must now be in the universe, and have always been! Can you think of the number? Not till you can think of infinity. The duration of life upon the globe, to say nothing of man's little span, is hardly a tick of this clock of eternity, and the repetition of the birth and dissipations of systems is well symbolized by the endless striking or ticking of a clock.

Then sooner or later comes the thought, What is it all for? and from the great abysm comes back the echo, "What for?" Is it our human limitations, the discipline of this earthly life, when we have to count the cost and ask what it is for, that makes us put the question to the Infinite? When the cosmic show is over, what is the gain? When our universe is again a blank, who or what will have 
reaped the benefit? Will the moral order which has been so slowly and painfully evolved, and which so many souls have struggled to live up to, still go on? Where? with whom? I seem to see dimly that you cannot bring the Infinite to book, that you cannot ask, "What for?" of the All, - of that which has neither beginning nor end, neither centre nor circumference, neither fulfillment nor design, which knows neither failure nor success, neither loss nor gain, and which is complete in and of itself.

We are tied to the sphere, its laws shape our minds, we cannot get away from it and see it in perspective; away from it there is no direction; at either pole on its surface there is the contradiction of the sky being always overhead. We are tied to the Infinite in the same way. We are part of it, but may not measure it. Our boldest thought comes back like a projectile fired into the heavens the curve of the infinite sphere holds us. I know I am trying to say the unsayable. I would fain indicate how human and hopeless is our question, "What for?" when asked of the totality of things. There is no totality of things. To say that there is, does not express it. To say there is not, does not express it. To say that the universe was created, does not express the mystery; to say that it was not created, but always existed, does not express it any nearer. To say that the heavens are overhead is only half the truth; they are underfoot also. 
Down is toward the centre of the earth, but go on through and come out at the surface on the other side, and which way is down then?

The Unspeakable will not be spoken.

In the light of science we must see that life and progress and evolution and the moral order must go on and on somewhere, that the birth of systems and the evolution of planets must and does continue, and always has continued; that if one sun fades, another blazes out; that as there must have been an infinite number (how can there be an infinite number? where is the end of the endless?) of worlds in the past, so there will be an infinite number in the future; that if the moral order and the mathematical order and the intellectual order disappear from one planet, they will appear in due time on another.

All that which in our limited view of nature we call waste and delay - how can such terms apply to the Infinite? Can we ever speak truly of the Infinite in terms of the finite? To be sure, we have no other terms, and can never have. Then let us be silent and - reverent. 


\section{STYLE AND THE MAN ${ }^{1}$}

TTHE difference between a precious stone and a

1 common stone is not an essential difference not a difference of substance, but of arrangement of the particles - the crystallization. In substance charcoal and the diamond are one, but in form and effect how widely they differ. The pearl contains nothing that is not found in the coarsest oyster shell.

Two men have the same thoughts; they use about the same words in expressing them; yet with one the product is real literature, with the other it is a platitude.

The difference is all in the presentation; a finer and more compendious process has gone on in the one case than in the other. The elements are better fused and welded together; they are in some way heightened and intensified. Is not here a clue to what we mean by style? Style transforms common quartz into an Egyptian pebble. We are apt to think of style as something external, that can be put on, something in and of itself. But it is not; it is in the

1 An excerpt from a chapter in Literary Values. 
inmost texture of the substance. Choice words, faultless rhetoric, polished periods, are only the accidents of style. Indeed, perfect workmanship is one thing ; style, as the great writers have it, is quite another. It.may, and often does, go with faulty workmanship. It is the use of words in a fresh and vital way, so as to give us a vivid sense of a new spiritual force and personality. In the best work the style is found and hidden in the matter.

If a writer does not bring a new thought, he must at least bring a new quality, - he must give a fresh, new flavor to the old thoughts. Style or quality will keep a man's work alive whose thought is essentially commonplace, as is the case with Addison; and Arnold justly observes of the poet Gray that his gift of style doubles his force and "raises him to a rank beyond what his natural richness and power seem to warrant."

There is the correct, conventional, respectable and scholarly use of language of the mass of writers, and there is the fresh, stimulating, quickening use of it of the man of genius. How apt and racy and telling is often the language of unlettered persons; the born writer carries this same gift into a higher sphere. Therc is a passage in one of Emerson's early letters, written when he was but twenty-four, and given by Mr. Cabot in his Memoir, which shows how clearly at that age Emerson discerned the secret of good writing and good preaching. 
"I preach half of every Sunday. When I attended church on the other half of a Sunday, and the image in the pulpit was all of clay, and not of tunable metal, I said to myself that if men would avoid that general language and general manner in which they strive to hide all that is peculiar, and would say only what is uppermost in their own minds, after their own individual manner, every man would be interesting. . . . But whatever properties a man of narrow intellect feels to be peculiar he studiously hides; he is ashamed or afraid of himself, and all his communications to men are unskillful plagiarisms from the common stock of thought and knowledge, and he is of course flat and tiresome."

The great mass of the writing and sermonizing of any age is of the kind here indicated; it is the result of the machinery of culture and of books and the schools put into successful operation. But now and then a man appears whose writing is vital; his page may be homely, but it is alive; it is full of personal magnetism. The writer does not merely give us what he thinks or knows; he gives us himself. There is nothing secondary or artificial between himself and his reader. It is books of this kind that mankind does not willingly let die. Some minds are like an open fire, - how direct and instant our communication with them; how they interest us; there are no screens or disguises; we see and feel the vital play of their thought; we are face to face with their 


\section{STYLE AND THE MAN}

spirits. Indeed all good literature, whether poetry or prose, is the open fire; there is directness, reality, charm; we get something at first-hand that warms and stimulates.

In literature proper our interest, I think, is always in the writer himself, - his quality, his personality, his point of view. We may fancy that we care only for the subject-matter; but the born writer makes any subject interesting to us by his treatment of it or by the personal element he infuses into it. When our concern is primarily with the subject-matter, with the fact or the argument, or with the information conveyed, then we are not dealing with literature in the strict sense. It is not so much what the writer tells us that makes literature, as the way he tells it; or rather, it is the degree in which he imparts to it some rare personal quality or charm that is the gift of his own spirit, something which cannot be detached from the work itself, and which is as inherent as the sheen of a bird's plumage, as the texture of a flower's petal. There is this analogy in nature. The hive bee does not get honey from the flowers; honey is a product of the bee. What she gets from the flowers is mainly sweet water or nectar; this she puts through a process of her own, and to it adds a minute drop of her own secretion, formic acid. It is her special personal contribution that converts the nectar into honey.

In the work of the literary artist, common facts 
and experiences are changed and heightened in the same way. Sainte-Beuve, speaking of certain parts of Rousseau's "Confessions," says, "Such pages were, in French literature, the discovery of a new world, a world of sunshine and of freshness, which men had near them without having perceived it." They had not perceived it because they had not had Rousseau's mind to mirror it for them. The sunshine and the freshness were a gift of his spirit. The new world was the old world in a new light. What charmed them was a quality personal to Rousseau. Nature they had always had, but not the Rousseau sensibility to nature. The same may be said of more recent writers upon outdoor themes. Readers fancy that in the works of Thoreau or of Jefferies some new charm or quality of nature is disclosed, that something hidden in field or wood is brought to light. They do not see that what they are in love with is the mind or spirit of the writer himself. Thoreau does not interpret nature, but nature interprets him. The new thing disclosed in bird and flower is simply a new sensibility to these objects in the beholder. In morals and ethics the same thing is true. Let an essayist like Dr. Johnson or Arthur Helps state a principle or an idea and it has a certain value; let an essayist like Ruskin or Emerson or Carlyle state the same principle and it has an entirely different value, makes an entirely different impression, - the qualities of mind and character of these writers are 
so different. The reader's relation with them is much more intimate and personal.

It is quality of mind which makes the writings of Burke rank above those of Gladstone, Ruskin's criticism above that of Hamerton, Froude's histories above Freeman's, Renan's “Life of Jesus" above that of Strauss; which makes the pages of Goethe, Coleridge, Lamb, literature in a sense that the works of many able minds are not. These men impart something personal and distinctive to the language they use. They make the words their own. The literary quality is not something put on. It is not of the hand, it is of the mind; it is not of the mind, but of the soul; it is of whatever is most vital and characteristic in the writer. It is confined to no particular manner and to no particular matter. It may be the gift of writers of widely different manners - of Carlyle as well as of Arnold; and in men of similar manners, one may have it and the other may not. It is as subtle as the tone of the voice or the glance of the eye. Quality is the one thing in life that cannot be analyzed, and it is the one thing in art that cannot be imitated. A man's manner may be copied, but his style, his charm, his real value, can only be parodied. In the conscious or unconscious imitations of the major poets by the minor, we get only a suggestion of the manner of the former; their essential quality cannot be reproduced. 
English literature is full of imitations of the Greek poets, but that which the Greek poets did not and could not borrow they cannot lend; their quality stays with them. The charm of spoken discourse is largely in the personal quality of the speaker something intangible to print. When we see the thing in print, we wonder how it could so have charmed or moved us. To convey this charm, this aroma of the man, to the written discourse is the triumph of style. A recent French critic says of Madame de Staël that she had no style; she wrote just as she thought, but without being able to impart to her writing the living quality of her speech. It is not importance of subject-matter that makes a work great, but importance of the subjectivity of the writer, - a great mind, a great soul, a great personality. A work that bears the imprint of these, that is charged with the life and power of these, which it gives forth again under pressure, is alone entitled to high rank.

All pure literature is the revelation of a man. In a work of true literary art the subject-matter has been so interpenetrated and vitalized by the spirit or personality of the writer, has become so thoroughly identified with it, that the two are one and inseparable, and the style is the man. Works in which this blending and identification, through emotion or imagination, of the author with his subject has not taken place, or has taken place imperfectly, 


\section{STYLE AND THE MAN}

do not belong to pure literature. They may serve a useful purpose; but all useful purposes, in the strict sense, are foreign to those of art, which means foreign to the spirit that would live in the whole, that would live in the years and not in the days, in time and not in the hour. The true literary artist gives you of the substance of his mind; not merely his thought or his philosophy, but something more intimate and personal than that. It is not a taygible object passed from his hand to yours; it is much more like a transfusion of blood from his veins to yours. Montaigne gives us Montaigne, - the most delightfully garrulous man in literature. "These are fancies of my own," he says, "by which I do not pretend to discover things, but to lay open myself." "Cut these sentences," says Emerson, "and they bleed." Matthew Arnold denied that Emerson was a great writer; but we cannot account for the charm and influence of his works, it seems to me, on any other theory than that he has at least this mark of the great writer: he gives his reader of his own substance, he saturates his page with the high and rare quality of his own spirit. Everything he published has a distinct literary value, as distinguished from its moral or religious value. The same may be said of Arnold himself: else we should not care much for him. It is a particular and interesting type of man that speaks and breathes in every sentence; his style is vital in his matter, and is no more sepa- 
rable from it than the style of silver or of gold is separable from those metals.

In such a writer as Lecky on the other hand, or as Mill or Spencer, one does not get this same subtle individual flavor; the work is more external, more the product of certain special faculties, as the reason, the memory, the understanding; and the personality of the author is not so intimately involved. But in the writer with the creative touch, whether he be poet, novelist, historian, critic, essayist, the chief factor in the product is always his own personality.

Style, then, in the sense in which I am bere using the term, implies that vital, intimate, personal relation of the man to his language by which he makes the words his own, fills them with his own quality, and gives the reader that lively sense of being in direct communication with a living, breathing, mental and spiritual force. The writer who appears to wield his language as an instrument or a tool, something exterior to himself, who makes you conscious of his vocabulary, or whose words are the garments and not the tissue of his thought, has not style in this sense. "Style," says Schopenhauer, "is the physiognomy of the mind, and a safer index to character than the face." This definition is as good as any, and better than most, because it implies that identification of words with thoughts, of the man with his subject, which is the secret of a living style. 


\section{STYLE AND THE MAN}

Hence the man who imitates another wears a mask, as does the man who writes in a language to which he was not born.

It has been said that novel-writing is a much finer art in our day than it was in the time of Scott, or of Dickens and Thackeray, - finer, I think, because it is in the hands of finer-strung, more daintily equipped men; but would one dare to say it is a greater art? One may admit all that is charged about Scott's want of style, his diffuseness and cumbrousness, and his tedious descriptions, and still justly claim for him the highest literary honors. He was a great nature, as Goethe said, and we come into vital contact with that great nature in his romances. He was not deficient in the larger art that knows how to make a bygone age live again to the imagination. He himself seems to have deprecated his " big bow-wow" style in comparison with the exquisite touches of Jane Austen. But no fineness of workmanship, no deftness of handling, can make up for the want of a large, rich, copious human endowment. I think we need to remember this when we compare unfavorably such men as Dickens and Thackeray with the cleverer artists of our own day. Scott makes up to us for his deficiencies in the matter of style by the surpassing human interest of his characters and incidents, their relations to the major currents 
of human life. His scenes fill the stage of history, his personages seem adequate to great events, and the whole story has a certain historic grandeur and impressiveness. There is no mistaking a great force, a great body, in literature any more than there is in the physical world; in Scott we have come upon a great river, a great lake, a great mountain, and we are more impressed by it than by the lesser bodies, though they have many more graces and prettinesses.

Frederic Harrison, in a recent address on style, is cautious in recommending the young writer to take thought of his style. Let him rather take thought of what he has to say; in turning his ideal values into the coin of current speech he will have an exercise in style. If he has no ideal values, then is literature barred to him. Let him cultivate his sensibilities ; make himself, if possible, more quickly responsive to life and nature about him; let him try to see more clearly and feel more keenly, and connect his vocabulary with his most radical and spontaneous self. Style can never come from the outside, - from consciously seeking it by imitating the manner of favorite authors. It comes, if at all, like the bloom upon fruit, or the glow of health upon the cheek, from an inner essential harmony and felicity.

In a well-known passage Macaulay tells what happened to Miss Burney when she began to think 
about her style, and fell to imitating Dr. Johnson; how she lost the "charming vivacity" and "perfectly natural unconsciousness of manner" of her youthful writings, and became modish and affected. She threw away her own style, which was a "tolerably good one," and which might "have been improved into a very good one," and adopted " a style in which she could attain excellence only by achieving an almost miraculous victory over nature and over habit. She could cease to be Fanny Burney; it was not so easy to become Samuel Johnson."

It is giving too much thought to style in the more external and verbal aspects of it, which $I$ am here considering, that leads to the confounding of style with diction, and that gives rise to the "stylist." The stylist shows you what can be done with mere words. He is the foliage plant of the literary flower garden. An English college professor has recently exploited him in a highly wrought essay on Style. Says our professor, "The business of letters is twofold, to find words for meaning and to find meaning for words." It strikes me that the last half of this proposition is not true of the serious writer, of the man who has something to say, but is true only of what is called the stylist, the man who has been so often described as one having nothing to say, which he says extremely well. The stylist's main effort is a verbal one, to find meaning for words; he does not wrestle with ideas, but with terms and phrases; 
his thoughts are word-begotten and are often as unsubstantial as spectres and shadows.

The stylist cultivates words as the florist cultivates flowers, and a new adjective or a new collocation of terms is to him what a new chrysanthemum or a new pansy is to his brother of the forcing house. He is more an European product than an American. London and Paris abound in men who cultivate the art of expression for its own sake, who study how to combine words so as to tickle the verbal sense without much reference to the value of the idea expressed. Club and university life, excessive library culture a sort of indoor or hothouse literary atmosphere - foster this sort of thing.

French literature can probably show more stylists than English, but the later school of British writers is not far behind in the matter of studied expression. Professor Raleigh, from whose work on style I quoted above, often writes forcibly and suggestively; but one cannot help but feel, on finishing his little volume, that it is more the work of a stylist than of a thinker. This is the opening sentence: "Style, the Latin name for an iron pen, has come to designate the art that handles, with ever fresh vitality and wary alacrity, the fluid elements of speech." Does not one faintly scent the stylist at the start? Later on he says: "In proportion as a phrase is memorable, the words that compose it become mutually adhesive, losing for a time something of their in- 
dividual scope, - bringing with them, if they be torn away too quickly, some cumbrous fragments of their recent association." Does not the stylist stand fully confessed here? That he may avoid these "cumbrous fragments" that will stick to words when you suddenly pull them up by the roots, "a sensitive writer is often put to his shifts, and extorts, if he be fortunate, a-triumph from the accident of his encumbrance." The lust of expression, the conjuring with mere words, is evident. "He is a poor stylist," says our professor, "who cannot beg half a dozen questions in a single epithet, or state the conclusion he would fain avoid in terms that startle the senses into clamorous revolt."

What it is in one that starts into "clamorous revolt" at such verbal gymnastics as are shown in the following sentences I shall not try to define, but it seems to me it is something real and legitimate. "A slight technical implication, a faint tinge of archaism in the common turn of speech that you employ, and in a moment you have shaken off the mob that scours the rutted highway, and are addressing a select audience of ticket holders with closed doors. A single natural phrase of peasant speech, a direct physical sense given to a word that genteel parlance authorizes readily enough in its metaphorical sense, and at a touch you have blown the roof off the drawing-room of the villa and have set its obscure inhabitants wriggling in the unaccustomed sunshine." 
Amiel says of Renan that science was his material rather than his object; his object was style. Yet Renan was not a stylist in the sense in which I am using the word. His main effort was never a verbal one, never an effort to find meaning for words; he was intent upon his subject; his style was vital in his thought, and never took on airs on its own account. You cannot in him separate the artist from the thinker, nor give either the precedence. All writers with whom literature is an art aim at style in the sense that they aim to present their subject in the most effective form, - with clcarness, freshness, force. They become stylists when their thoughts wait upon their words, or when their thoughts are word-begotten. Such writers as Gibbon, De Quincey, Macaulay, have studied and elaborate styles, but in each the matter is paramount and the mind finds something solid to rest upon.

"The chief of the incommodities imposed upon the writer," says Professor Raleigh, is "the necessity at all times and at all costs to mean something," or to find meaning for words. This no doubt is a hard task. The trouble begins when one has the words first. To invoke ideas with words is a much more difficult experience than the reverse process. But probably all true writers have something to say before they have the desire to say it, and in proportion as the thought is vital and real is its expression easy. 
When I meet the stylist, with his straining for verbal effects, I love to recall this passage from Whitman. "The great poet," he says, "swears to his art, I will not be meddlesome. I will not have in my writing any elegance or effect or originality to hang in the way between me and the rest, like curtains. I will have nothing hang in the way, not the richest curtains. What I tell I tell for precisely what it is. Let who may, exalt or startle or fascinate or soothe; I will have purpose, as health or heat or snow has, and be as regardless of observation. What I experience or portray shall go from my composition without a shred of my composition. You shall stand by my side and look in the mirror with me."

This is the same as saying that the great success in writing is to get language out of the way and to put your mind directly to the reader's, so that there be no veil of words betwcen you. If the reader is preoccupied with your words, if they court his attention or cloud his vision, to that extent is the communication imperfect. In some of Swinburne's poems there is often such a din and echo of rhyme and alliteration that it is almost impossible to hear what the man is really saying.

To darken counsel with words is a common occurrence. Words are like lenses, - they must be arranged in just such a way, or they hinder rather than help the vision. When the adjustment is as it should be, the lens itself is invisible; and language in 
the hands of the master is as transparent. Some of the more recent British poets affect the archaic, the quaint, the eccentric, in language, so that one's attention is almost entirely occupied with their words. Reading them is like trying to look through a pair of spectacles too old or too young for you, or with lenses of different focus.

But has not style a value in and of itself? As in the case of light, its value is in the revelation it makes. Its value is to conceal itself, to lose itself in the matter. If humility, or self-denial, or any of the virtues becomes conscious of itself and claims credit for its own sake, does it not that moment fall from grace? What incomparable style in the passage I have quoted from Whitman when we come to think of it, but how it effaces itself and is of no account for the sake of the idea it serves! The more a writer's style humbles itself, the more it is exalted. There is nothing true in religion that is not equally true in art. Give yourself entirely. All selfish and secondary ends are of the devil. Our Calvinistic grandfathers, who fancied themselves willing to be damned for the glory of God, illustrate the devotion of the true artist to his ideal. "Consider the lilies of the field,... they toil not, neither do they spin." The style of the born poet or artist takes as little thought of itself, and is the spontaneous expression of the same indwelling grace and necessity. 


\section{STYLE AND THE MAN LIP 99}

There are as many styles as there are moods and tempers in men. Words may be used so as to give us a sense of vigor, a sense of freshness, a sense of the choice and scholarly, or of the dainty and exclusive, or of the polished and elaborate, or of heat or cold, or of any other quality known to life. Every work of genius has its own physiognomy - sad, cheerful, frowning, yearning, determined, meditative. This book has the face of a saint; that of a scholar or a seer. Here is the feminine, there the masculine face. One has the clerical face, one the judicial. Each appeals to us according to our temperaments and mental predilections. Who shall say which style is the best? What can be better than the style of Huxley for his purpose, - sentences level and straight like a hurled lance; or than Emerson's for his purpose, - electric sparks, the sudden, unexpected epithet or tense, audacious phrase, that gives the mind a wholesome shock; or than Gibbon's for his purpose, - a style like solid masonry, every sentence cut four square, and his work, as Carlyle said to Emerson, a splendid bridge, connecting the ancient world with the modern; or than De Quincey's for his purpose, - a discursive, roundabout style, herding his thoughts as a collie dog herds sheep; or than Arnold's for his academic spirit, - a style like cut glass; or than Whitman's for his continental spirit, - the processional, panoramic style 
that gives the sense of mass and multitude? Certain things we may demand of every man's style, - that it shall do its work, that it shall touch the quick. To be colorless like Arnold is good, and to have color like Ruskin is good; to be lofty and austere like the old Latin and Greek authors is good, and to be playful and discursive like Dr. Holmes is good; to be condensed and epigrammatic like Bacon pleases, and to be flowing and copious like Macaulay pleases. Within certain limits the manner that is native to the man, the style that is a part of himself, is what wears best. What we do not want in any style is hardness, glitter, tumidity, superfetation, unreality .

In treating of nature or outdoor themes, let the style have limpidness, sweetness, freshness; in criticism let it have dignity, lucidity, penetration; in history let it have mass, sweep, comprehension; in all things let it have vitality, sincerity, and genuineness. 


\section{SUGGESTIVENESS ${ }^{1}$}

THERE is a quality that adheres to one man's 1 writing or speaking, and not to another's, that we call suggestiveness, - something that warms and stimulates the mind of the reader or hearer, quite apart from the amount of truth or information directly conveyed.

It is a precious literary quality, not easy of definition or description. It involves quality of mind, mental and moral atmosphere, points of view, and maybe, racial elements. Not every page or every book carries latent meaning; rarely does any sentence of a writer float deeper than it shows.

Thus, of the great writers of English literature, Dr. Johnson is, to me, the least suggestive, while Bacon is one of the most suggestive. Hawthorne is undoubtedly the most suggestive of our romancers; he has the most atmosphere and the widest and most alluring horizon. Emerson is the most suggestive of our essayists, because he has the deepest ethical and prophetic background. His page is full of moral electricity, so to speak, which begets a state of electric excitement in his reader's mind. Whitman is the

1 From Literary Values. 
most suggestive of our poets; he elaborates the least and gives us in profusion the buds and germs of poetry. A musical composer once said to me that Whitman stimulated him more than Tennyson, because he left more for him to do, - he abounded in hints and possibilities that the musician's mind eagerly seized.

This quality is not related to ambiguity of phrase or to cryptic language or to vagueness and obscurity. It goes, or may go, with perfect lucidity, as in Matthew Arnold at his best, while it is rarely present in the pages of Herbert Spencer. Spencer has great clearness and compass, but there is nothing resonant in his style, - nothing that stimulates the imagination. He is a great workman, but the metal he works in is not of the kind called precious.

The late roundabout and enigmatical style of Henry James is far less fruitful in his readers' minds. than his earlier and more direct one, or than the limpid style of his compeer, Mr. Howells. The indirect and elliptical method may undoubtedly be so used ai to stimulate the mind; at the same time there may be a kind of inconclusiveness and beating around the bush that is barren and wearisome. Upon the page of the great novelist there fall, more or less distinct, all the colors of the spectrum of human life; but Mr. James in his later works seems intent only upon the invisible rays of the spectrum, and his readers grope in the darkness accordingly. 
In the world of experience and observation the suggestiveness of things is enhanced by veils, concealments, half lights, flowing lines. The twilight is more suggestive than the glare of noonday, a rolling field than a lawn, a winding road than a straight one. In literature perspective, indirection, understatement, side glimpses, have equal value; a vocabulary that is warm from the experience of the writer, sentences that start a multitude of images, that abound in the concrete and the specific, that shun vague generalities, - with these goes the power of suggestiveness.

Beginnings, outlines, summaries, are suggestive, while the elaborated, the highly wrought, the perfected afford us a different kind of pleasure. The art that fills and satisfies us has one excellence, and the art that stimulates and makes us ahungry has another. All beginnings in nature afford us a peculiar pleasure. The early spring with its hints and dim prophecies, the first earth odors, the first robin or song sparrow, the first furrow, the first tender skies, the first rainbow, the first wild flower, the dropping bud scales, the awakening voices in the marshes, - all these things touch and move us in a way that later developments in the season do not. What meaning, too, in the sunrise and the sunset, in the night with its stars, the sea with its tides and currents, the morning with its dews, autumn with its bounty, winter with its snows, the desert with its 
sands, - in everything in the germ and in the bud, - in parasites, suckers, blights, in floods, tempests, droughts! The winged seeds carry thoughts, the falling leaves make us pause, the clinging burrs have a tongue, the pollen dust, not less than meteoric dust. conveys a hint of the method of nature.

Some things and events in our daily experience are more typical, and therefore more suggestive, than others. Thus the sower striding across the ploughed field is a walking allegory, or parable. Indeed the whole life of the husbandman, - his first-hand relation to things, his ploughing, his planting, his fertilizing, his draining, his pruning, his grafting, his uprootings, his harvestings, his separating of the wheat from the chaff, and the tares from the wheat, his fencing his field with the stones and boulders that hindered his plough or cumbered his sward, his making the wilderness blossom as the rose, - all these things are pleasant to contemplate because in them there is a story within a story, we translate the facts into higher truths.

In like manner, the shepherd with his flocks, the seaman with his compass and rudder, the potter with his clay, the weaver with his warp and woof, the sculptor with his marble, the painter with his canvas and pigments, the builder with his plans and scaffoldings, the chemist with his solvents and precipitants, the surgeon with his scalpel and antiseptics, the lawyer with his briefs, the preacher with 
his text, the fisherman with his nets, - all are more or less symbolical and appeal to the imagination.

In both prose and poetry, there is the suggestiveness of language used in a vivid, imaginative way, and the suggestiveness of words redolent of human association, words of deep import, as friend, home, love, marriage.

To me Shakespeare's sonnets are the most suggestive sonnets in the language, because they so abound in words, images, allusions drawn from real life; they are the product of a mind vividly acted upon by near-by things, that uses language steeped in the common experience of mankind. The poet drew his material not from the strange and the remote, but, as it were, from the gardens and thoroughfares of life. Does not that poetry or prose work touch us the most nearly that deals with that with which we are most familiar? One thing that separates the minor poet from the major is that the thoughts and words of the minor poet are more of the nature of asides, or of the exceptional; he does not take in the common and universal; we are not familiar with the points of view that so agitate him; and he has not the power to make them real to us. I read poems every day that provoke the thought, "Well, that is all news to me. I do not know that heaven or that earth, those men or those women," - all is so shadowy, fantastic, and unreal. But when you enter the world of the great poets you find yourself upon solid 
ground; the sky and the earth, and the things in them and upon them, are what you have always known, and not for a moment are you called upon to breathe in a vacuum, or to reverse your upright position to see the landscape. Dante even makes hell as tangible and real as the objects of our senses, if not more so.

Then there is the suggestiveness or kindling power of pregnant, compact sentences, - type thoughts, compendious phrases, - vital distinctions or generalizations, such as we find scattered through literature, as when De Quincey says of the Roman that he was great in the presence of man, never in the presence of nature; or his distinction between the literature of power and the literature of knowledge, or similar illuminating distinctions in the prose of Wordsworth, Coleridge, Carlyle, Arnold, Goethe, Lessing. Arnold's dictum that poetry is a criticism of life, is suggestive, because it sets you thinking to verify or to disprove it. John Stuart Mill was not what one would call a suggestive writer, yet the following sentence, which Mr. Augustine Birrell has lately made use of, makes a decided ripple in one's mind: "I have learnt from experience that many false opinions may be exchanged for true ones without in the least altering the habits of mind of which false opinions are the result." In a new home writer whose first books are but a year or two old, I find deeply suggestive sentences on nearly every page. 
Here are two or three of them: "In your inmost soul you are as well suited to the whole cosmical order and every part of it as to your own body. You belong here. Did you suppose that you belonged to some other world than this, or that you belonged nowhere at all, just a waif on the bosom of the eternities?... Conceivably He might have flung you into a world that was unrelated to you, and might have left you to be acclimated at your own risk; but you happen to know that this is not the case. You have lived here always; this is the ancestral demesne; for ages and ages you have looked out of these same windows upon the celestial landscape and the star-deeps. You are at home." "How perverse and pathetic the desires of the animals! But they all get what they ask for, - long necks and trunks, flapping ears and branching horns and corrugated hides, anything, if only they will believe in life and try." 1

The intuitional and affirmative writers, to which class our new author belongs, and the most notable example of which, in this country, was Emerson, are, as a rule, more suggestive than the clearly demonstrating and logical writers. A challenge to the soul seems to mean more than an appeal to the reason; an audacious affirmation often irradiates the mind in a way that a logical sequence of thought does not. Science rarely suggests more than it says;

1 The Religion of Democracy. By Charles Ferguson. 


\section{SUGGESTIVENESS}

but in the hands of an imaginative man like Maeterlinck a certain order of facts in natural history becomes fraught with deepest meaning, as may be witnessed in his wonderful "Life of the Bee," - one of the most enchanting and poetic contributions to natural history ever made. Darwin's work upon the earthworm, and upon the cross fertilization of flowers, in the same way seems to convey more truth to the reader than is warranted by the subject.

The writer who can touch the imagination has the key, at least one key, to suggestiveness. This power often goes with a certain vagueness and in. definiteness, as in the oft-quoted lines from one of Shakespeare's sonnets:-

\section{"the prophetic soul}

Of the wide world dreaming on things to come ;"

a very suggestive, but not a clearly intelligible passage.

Truth at the centre, straightly put, excites the mind in one way, and truth at the surface, or at the periphery of the circle, indirectly put, excites it in another way and for other reasons; just as a light in a dark place, which illuminates, appeals to the eye in a different way from the light of day falling through vapors or colored glass, wherein objects become softened and illusory.

A common word may be so used as to have an 
unexpected richness of meaning, as when Coleridge speaks of those books that "find" us; or Shakespeare of the "marriage of true minds," or Whitman of the autumn apple hanging "indolent-ripe" on the tree. Probably that language is the most suggestive that is the most concrete, that is drawn most largely from the experience of life, that savors of real things. The Saxon English of Walton or Barrow is more suggestive than the latinized English of Johnson or Gibbon.

Indeed, the quality I am speaking of is quite exceptional in the eighteenth-century writers. It is much more abundant in the writers of the seventeenth century. It goes much more with the vernacular style, the homely style, than with the polished academic style.

With the stream of English literature of the nineteenth century has mingled a current of German thought and mysticism, and this has greatly heightened its power of suggestiveness both in poetry and in prose. It is not in Byron or Scott or Campbell or Moore or Macaulay or Irving, but it is in Wordsworth and Coleridge and Landor and Carlyle and Ruskin and Blake and Tennyson and Browning and Emerson and Whitman, - a depth and richness of spiritual and emotional background that the wits of Pope's and Johnson's times knew not of. It seems as if the subconscious self played a much greater part in the literature of the nineteenth century than 
of the eighteenth, probably because this term has been recently added to our psychology.

As a rule it may be said that the more a writer condenses, the more suggestive his work will be. There is a sort of mechanical equivalent between the force expended in compacting a sentence and the force or stimulus it imparts again to the reader's mind. A diffuse writer is rarely or never a suggestive one. Poetry is, or should be, more suggestive than prose, because it is the result of a more compendious and sublimating process. The mind of the poet is more tense, he uses language under greater pressure of emotion than the prose writer, whose medium of expression gives his mind more play-room. The poet often succeeds in focusing his meaning or emotion in a single epithet, and he alone gives us the resounding, unforgettable line. There are pregnant sentences in all the great prose writers; there are immortal lines only in the poets.

Whitman said the word he would himself use as most truly descriptive of his "Leaves of Grass" was the word suggestiveness. "I round and finish little, if anything; and could not consistently with my scheme. The reáder will always have his or her part to do, just as much as I have had mine. I seek less to state or display my theme or thought, and more to bring you, reader, into the atmosphere of the theme or thought - there to pursue your own 
flight." These sentences themselves are suggestive, because they bring before the mind a variety of definite actions, as finishing a thing, displaying a thing, doing your part, pursuing your own flight, and yet the idea conveyed has a certain subtlety and elusiveness. The suggestiveness of his work as a whole probably lies in its blending of realism and mysticism, and in the art of it running parallel to or in some way tallying with the laws and processes of nature. It stimulates thought and criticism as few modern works do.

Of course the suggestiveness of any work - poem, picture, novel, essay - depends largely upon what we bring to it; whether we bring a kindred spirit or an alien one, a full mind or an empty one, an alert sense or a dull one. If you have been there, so to speak, if you have passed through the experience described, if you have known the people portrayed, if you have thought, or tried to think, the thoughts the author exploits, the work will have a deeper meaning to you than to one who is a stranger to these things. The best books make us acquainted with our own, - they help us to find ourselves. No book calls forth the same responses from two different types of mind. The wind does not awaken æolian-harp tones from cornstalks. No man is a hero to his valet. It is the deep hollows and passes of the mountains that give back your voice in prolonged reverberations. The tides are in the sea, not 
in the lakes and ponds. Words of deep import do not mean much to a child. The world of books is under the same law as these things. What any given work yields us depends largely upon what we bring to it. 

UNIVERSITY OF CALIFORNIA LIBRARY

\section{Los Angeles}

This book is DUE on the last date stamped below.

\section{THE LIBRARY}


PS Burroughs. -

1224 Studies in natur \$93 and literature.
A 0013726658

\section{PS}

1224 593 
